\title{
Effects of Substituents on Photophysical and CO-Photoreleasing Properties of 2,6-Substituted meso-Carboxy BODIPY Derivatives ${ }^{\dagger}$
}

\author{
Esther M. Sánchez-Carnerero ${ }^{1, \ddagger}$, Marina Russo ${ }^{1, \ddagger} \mathbb{D}$, Andreas Jakob ${ }^{1}$, Lucie Muchová ${ }^{\mathbb{D}}$, Libor Vítek ${ }^{2,3} \mathbb{D}$ \\ and Petr Klán 1,*iD
}

check for updates

Citation: Sánchez-Carnerero, E.M.; Russo, M.; Jakob, A.; Muchová, L.; Vítek, L.; Klán, P. Effects of Substituents on Photophysical and CO-Photoreleasing Properties of 2,6-Substituted meso-Carboxy BODIPY Derivatives . Chemistry 2021, 3, 238-255. https://doi.org/ 10.3390/chemistry3010018

Received: 10 December 2020

Accepted: 4 February 2021

Published: 9 February 2021

Publisher's Note: MDPI stays neutral with regard to jurisdictional claims in published maps and institutional affiliations.

Copyright: (c) 2021 by the authors. Licensee MDPI, Basel, Switzerland. This article is an open access article distributed under the terms and conditions of the Creative Commons Attribution (CC BY) license (https:// creativecommons.org/licenses/by/ $4.0 /)$.
1 Department of Chemistry and RECETOX, Faculty of Science, Masaryk University, Kamenice 5, 62500 Brno, Czech Republic; emmarque@ucm.es (E.M.S.-C.); russomarina.mr@gmail.com (M.R.); Jakob.Andreas@gmx.de (A.J.)

2 Institute of Medical Biochemistry and Laboratory Diagnostics, General University Hospital and 1st Faculty of Medicine, Charles University, Kateřinská 32, 12108 Praha 2, Czech Republic; lucie.muchova@lf1.cuni.cz (L.M.); vitek@cesnet.cz (L.V.)

3 4th Department of Internal Medicine, General University Hospital, and 1st Faculty of Medicine, Charles University, Kateřinská 32, 12108 Praha 2, Czech Republic

* Correspondence: klan@sci.muni.cz

+ Dedicated to Prof. Josef Michl on the occasion of his 80th birthday.

$\ddagger$ These authors contributed equally to this work.

\begin{abstract}
Carbon monoxide (CO) is an endogenously produced signaling molecule involved in the control of a vast array of physiological processes. One of the strategies to administer therapeutic amounts of $\mathrm{CO}$ is the precise spatial and temporal control over its release from photoactivatable CO-releasing molecules (photoCORMs). Here we present the synthesis and photophysical and photochemical properties of a small library of meso-carboxy BODIPY derivatives bearing different substituents at positions 2 and 6 . We show that the nature of substituents has a major impact on both their photophysics and the efficiency of $\mathrm{CO}$ photorelease. $\mathrm{CO}$ was found to be efficiently released from $\pi$-extended 2,6-arylethynyl BODIPY derivatives possessing absorption spectra shifted to a more biologically desirable wavelength range. Selected photoCORMs were subjected to in vitro experiments that did not reveal any serious toxic effects, suggesting their potential for further biological research.
\end{abstract}

Keywords: BODIPY; photochemistry; carbon monoxide; photorelease; carbon monoxide-releasing molecules

\section{Introduction}

4,4-Difluoro-4-bora-3a,4a-diaza-s-indacene (BODIPY) dyes have attracted increasing attention in bioapplications [1,2] as sensors [3-5] or fluorescent tags [6,7] for their high molar absorption coefficients, sharp and intense fluorescence emission bands, chemical stability, and low toxicity [8]. Synthetic methods are available to fine-tune the dye structure to achieve the required spectroscopic and photophysical characteristics [9-12]. The intersystem crossing (ISC) efficiency in most BODIPY fluorophores is usually small, which precludes their use as triplet photosensitizers [13]. Specific structural modifications, such as the introduction of iodine or bromine atoms as core substituents $[8,14,15]$, can enhance ISC thanks to a strong spin-orbit coupling [16] between the singlet and triplet states (heavy atom effect) $[17,18]$.

It has been found that, despite its overt toxicity when present in high concentrations, carbon monoxide ( $\mathrm{CO}$ ) as an endogenously produced signaling molecule can have beneficial effects in various physiological processes and cellular functions, including apoptosis, proliferation, and inflammation at sub-micromolar concentrations $(\approx 0.2 \mu \mathrm{M})$ [19-21]. 
When considering its therapeutic applications, sufficiently low concentrations of CO must be administered in a controlled manner to avoid its toxic effects. One CO delivery strategy is based on metal carbonyl complexes that release a weakly bound $\mathrm{CO}$ by simple hydrolytic ligand exchange upon dissolution in aqueous media [22,23]. Another approach is the use of photochemically activatable CO-releasing molecules (photoCORMs), which allow precise spatial and temporal control over its release in tissues [24-28]. Visible/NIR light has a reduced tissue penetration due to high optical scattering and strong absorbance by endogenous chromophores, such as hemoglobin or melanin [29,30]; therefore, photoCORMs activatable in this wavelength range are highly desirable. Most of the reported visible/NIR light-absorbing photoCORMs are metal carbonyl complexes, but several transition-metal-free (organic) photoCORMs, such as xanthene-9-carboxylic acid [31] or flavonol derivatives [32-35], have also been designed and studied. Some of us have introduced meso-carboxy BODIPY-based photoCORM derivatives $\mathbf{1 a}$ and $\mathbf{b}$ that can release $\mathrm{CO}$ upon irradiation at wavelengths of up to $\approx 750 \mathrm{~nm}$ (Scheme 1) [36]. The density functional theory (DFT) calculations suggested that a strained $\alpha$-lactone intermediate, formed upon irradiation via a triplet biradical, is responsible for the subsequent $\mathrm{CO}$ liberation.

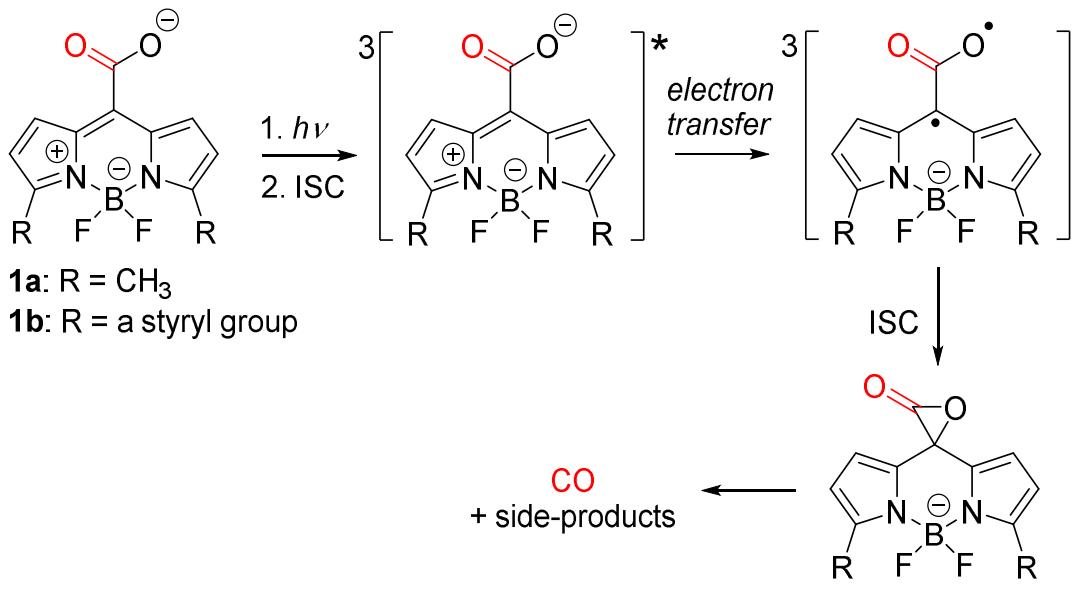

Scheme 1. Carbon monoxide photorelease from meso-carboxy BODIPY derivatives.

In this work, we prepared several meso-carboxy BODIPY derivatives of $\mathbf{2}$, compounds 3-10 (Figure 1), as potential new BODIPY-based photoCORMs, and studied their photophysical and photochemical properties. We evaluated the effects of various electrondonating and electron-withdrawing substituents at positions 2 and 6 on their absorption and emission properties, and the efficiencies of $\mathrm{CO}$ release and singlet oxygen production upon irradiation. The selected derivatives with the highest yields of $\mathrm{CO}$ were subjected to cell culture experiments to determine possible cytotoxic effects to assess their potential for future therapeutic use. 
<smiles></smiles>

2<smiles></smiles>

3<smiles></smiles>

4<smiles></smiles>

5<smiles></smiles>

6<smiles></smiles>

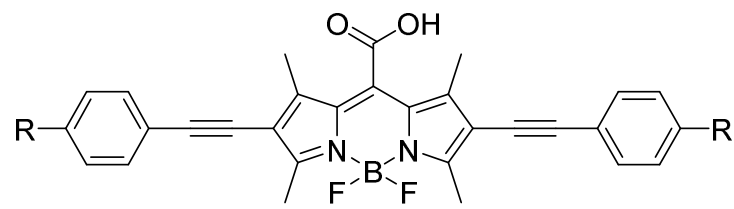

7

$$
\begin{aligned}
& \text { 8: } \mathrm{R}=\mathrm{H} \\
& \text { 9: } \mathrm{R}=\mathrm{OCH}_{3}
\end{aligned}
$$$$
\text { 10: } R=\gamma_{0} \gamma_{3}
$$

Figure 1. meso-Carboxy BODIPY derivatives $\mathbf{2}-\mathbf{1 0}$ studied in this work.

\section{Results and Discussion}

Synthesis: Methyl and benzyl esters of carboxylic acid derivative 2, compounds 11 and 12, were prepared from 2,4-dimethylpyrrole and the corresponding chlorooxalate in 34 and $31 \%$ chemical yields (Scheme 2), respectively, using a modified procedure previously described [37]. Compound 12 was treated with $\mathrm{POCl}_{3}$ in $\mathrm{DMF}$ to give aldehyde 13 as a synthetic precursor, which was subsequently converted to carboxylic acid $\mathbf{1 4}$ in the presence of $\mathrm{NaClO}_{2}$ and $\mathrm{NH}_{2} \mathrm{SO}_{3} \mathrm{H}$ in $55 \%$ yield (Scheme 3). Compound 13 was used for the preparation of oxime $\mathbf{1 5}$ by the reaction with hydroxylamine hydrochloride and sodium hydroxide in ethanol (52\% yield), and then the resulting $\mathbf{1 5}$ was treated with oxalyl chloride in acetonitrile to give 2-cyano derivative $\mathbf{1 6}$ in 78\% yield (Scheme 3 ).

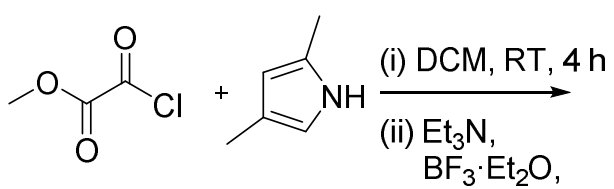
$0^{\circ} \mathrm{C}$ to RT, $8 \mathrm{~h}$<smiles>OCc1ccccc1</smiles><smiles>O=C(Cl)C(=O)OCc1ccccc1</smiles><smiles>COC(=O)c1c(C)cc(C)n1B(F)F</smiles>

$11(34 \%)$

(i)<smiles>Cc1c[nH]c(C)c1</smiles>
$\mathrm{DCM}$, $-78^{\circ} \mathrm{C}, 4 \mathrm{~h}$

(ii) $\mathrm{Et}_{3} \mathrm{~N}$, $\mathrm{BF}_{3}-\mathrm{Et}_{2} \mathrm{O}$ $0-20^{\circ} \mathrm{C}, 8 \mathrm{~h}$

Scheme 2. Synthesis of methyl and benzyl esters $\mathbf{1 1}$ and $\mathbf{1 2}$. 

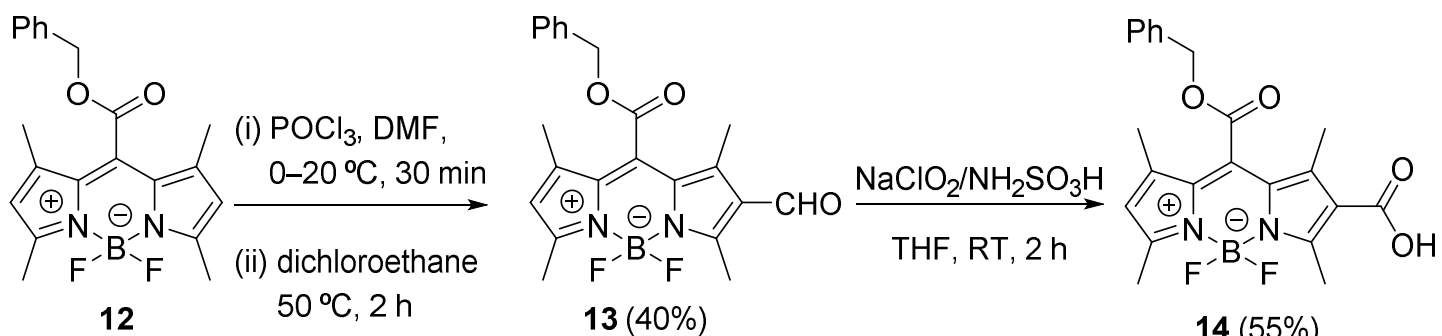

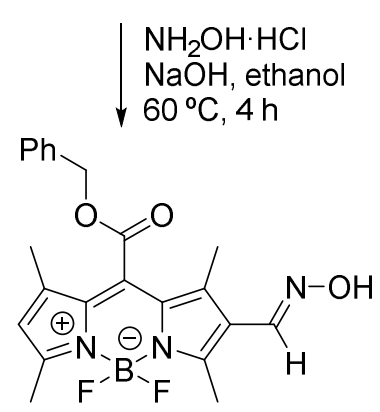

$15(52 \%)$

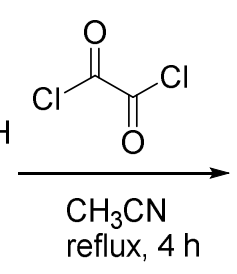<smiles>Cc1cc(C)n(B(F)F)c1C(C(=O)OCc1ccccc1)c1c(C)c(C#N)c(C)n1B(F)F</smiles>

$16(78 \%)$

Scheme 3. Synthesis of benzyl esters $\mathbf{1 4}$ and $\mathbf{1 6 .}$

2,6-Diiodo derivative 17, obtained by the reaction of 11 with iodine monochloride in dichloromethane in an excellent yield (91\%), was used for the preparation of 2,6-diphenyl analog 18 by Suzuki-Miyaura cross-coupling reaction in 76\% yield (Scheme 4). Compound 17 was used for the preparation of 2,6-diethynylbenzene derivatives 19-21 by Sonogashira cross-coupling reactions in good yields (73-83\%; Scheme 4$)$.

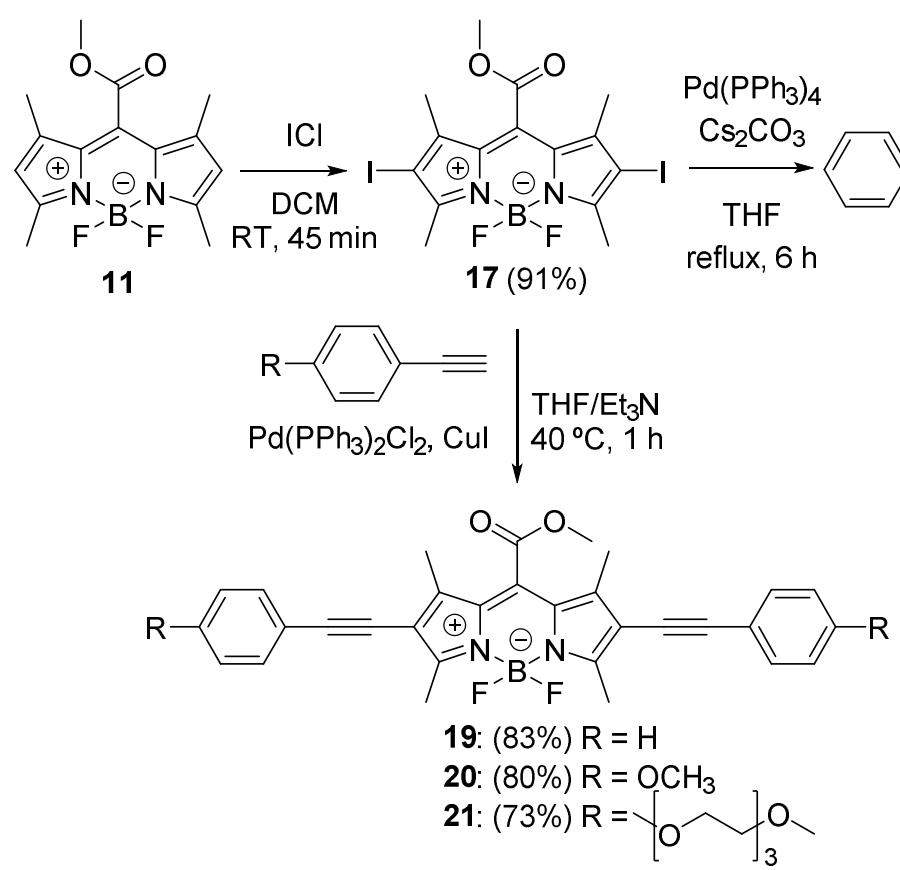

Scheme 4. Synthesis of 2,6-diphenyl (18) and 2,6-diethynyl (19-21) esters.

The target meso-carboxy BODIPY derivatives $\mathbf{2}$ and $\mathbf{4 - 1 0}$ were obtained by the deprotection of the corresponding methyl esters using lithium iodide or by catalytic hydrogenation from the benzyl esters in good isolated yields (65-92\%; Scheme 5). 2,6-Dibromo analog 3 was prepared by the reaction of 2 with NBS in $49 \%$ yield (Scheme 5 ). 

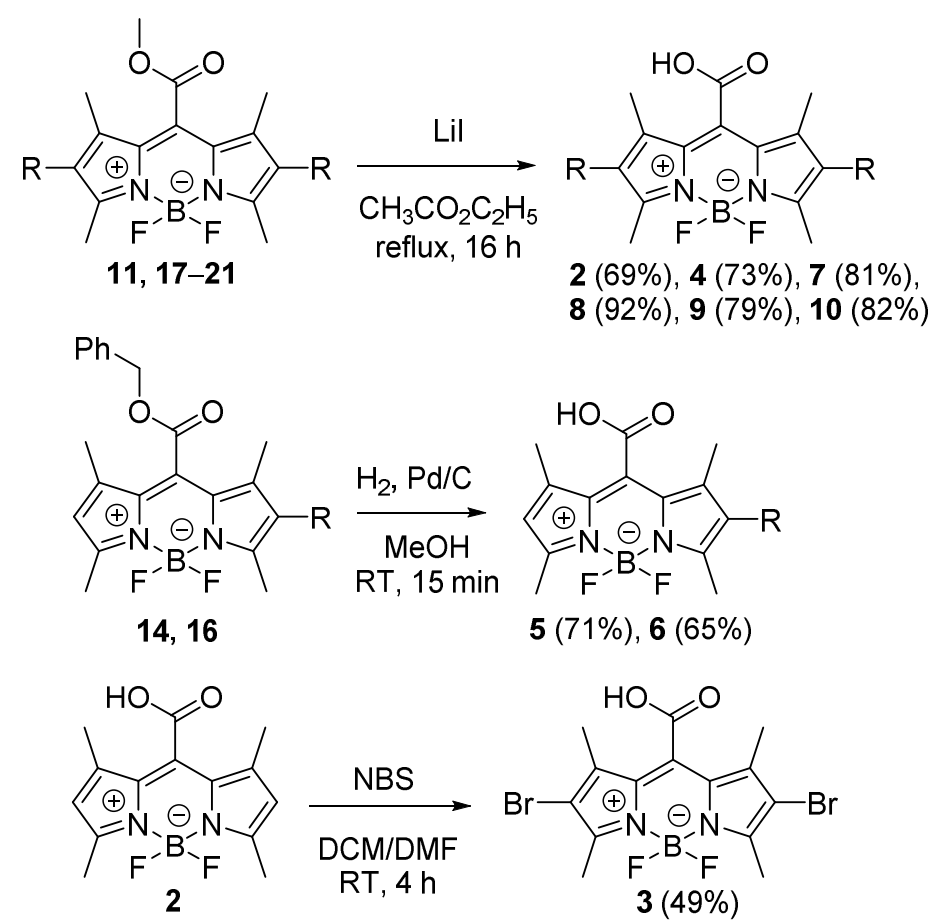

Scheme 5. Synthesis of meso-carboxy BODIPYs derivatives 2-10.

Photophysical properties of BODIPY derivatives 2-10: The absorption and emission spectra of compounds 2-10 in methanol or phosphate buffered saline (PBS)/DMSO mixtures are shown in Tables 1 and 2 and Figures S57-S73. The absorption $\left(\lambda_{\max }^{\text {abs }}\right)$ and emission $\left(\lambda_{\max }^{\mathrm{em}}\right)$ maxima of BODIPYs $\mathbf{3} \mathbf{- 5}$ and $\mathbf{7 - 1 0}$ are bathochromically shifted compared to those of the reference derivative 2 , particularly in the case of $\pi$-extended ethynyl [38-40] derivatives 8-10. Both $\lambda_{\max }^{\mathrm{abs}}$ and $\lambda_{\max }^{\mathrm{em}}$ of 6 , bearing an electron-withdrawing group at position 2 , are slightly hypsochromically shifted. The molar absorption coefficients $(\varepsilon)$ were found to be in the range of 3.2-5.8 $\times 10^{4} \mathrm{M}^{-1} \mathrm{~cm}^{-1}$, which is common for BODIPY chromophores [11]. The type of the solvent (methanol, Table 1, and PBS, Table 2) had only a marginal effect on the $\lambda_{\max }^{\mathrm{abs}}, \lambda_{\max }^{\mathrm{em}}$, and $\varepsilon$ values. The solvent and properties of the substituents at positions 2 and 6 had a substantial effect on the fluorescence quantum yields $\left(\Phi_{\mathrm{f}}\right)$. Except for compound 2, all $\Phi_{\mathrm{f}}$ values were found to be higher in methanol; indeed, increasing the solvent polarity leads to a low fluorescence efficiency of BODIPY derivatives [12]. Besides, the $\Phi_{\mathrm{f}}$ was found to be relatively small for bromo- and iodo- derivatives 3 and 4 due to the presence of heavy atoms (i.e., an efficient ISC). An efficient nonradiative decay must also be responsible for the small values of $\Phi_{\mathrm{f}}$ in the case of 2-cyano (6) and 2-phenylethynyl (9 and 10) derivatives. This is consistent with the low $\Phi_{\mathrm{f}}$ found for 2-phenylethynyl $[38,41]$ or 2,6-arylethynyl [40] BODIPY derivatives. Analogous meso-alkenyl substituted BODIPYs have also been reported to be practically non-fluorescent [39,42]. It has been explained by the effect of large stabilization upon excitation along with the bending of the fused BODIPY core, and the accessible $S_{1} / S_{0}$ conical intersection point [16]; the small geometrical evolution prompts the nonradiative relaxation to the ground state [43]. We also cannot exclude fluorescence quenching by internal charge transfer (ICT) in derivatives 9 and $10[42,44,45]$. Different amounts of DMSO were added to PBS to dissolve the BODIPY derivatives because, except for $\mathbf{1 0}$ (the $p$-phenyl polyethylene glycol substituents were introduced in $\mathbf{1 0}$ to improve its solubility in aqueous solutions), they are only partially soluble in aqueous solutions. The $\mathrm{pK}_{\mathrm{a}}$ of non-substituted meso-carboxy BODIPY derivatives has previously been determined to be 4.7; the absorption band of the conjugate acid is bathochromically shifted by $\approx 100 \mathrm{~nm}[36]$. The $\mathrm{pH}$ titration of 9 in a PBS/methanol (95:5, $v / v)$ solution showed that the signal of the conjugate acid appears at $\approx 680 \mathrm{~nm}$ and a $\mathrm{pH}$ 
below 5 (Figure S99). BODIPY derivatives were present only as conjugate base forms in solutions under the experimental conditions used in this work.

Table 1. Photophysical properties of meso-Carboxy BODIPY derivatives in methanol.

\begin{tabular}{|c|c|c|c|c|c|}
\hline Compound & $\lambda_{\max }^{\mathrm{abs}} / \mathrm{nm}$ & $\varepsilon / 10^{4} \mathrm{M}^{-1} \mathrm{~cm}^{-1}$ & $\lambda_{\max }^{\mathrm{em}} / \mathbf{n m}$ & $\Phi_{\mathrm{f}}{ }^{a}$ & $\Phi_{\Delta}^{b}$ \\
\hline 2 & 494 & 5.22 & 504 & $0.37 \pm 0.03$ & $0.044 \pm 0.003$ \\
\hline 3 & 516 & 5.61 & 531 & $0.24 \pm 0.02$ & $0.59 \pm 0.05$ \\
\hline 4 & 521 & 5.83 & 540 & $0.03 \pm 0.002$ & $0.72 \pm 0.05$ \\
\hline 5 & 490 & 3.95 & 502 & $0.37 \pm 0.02$ & $0.055 \pm 0.005$ \\
\hline 6 & 481 & 4.07 & 500 & $0.108 \pm 0.003$ & $0.07 \pm 0.01^{c}$ \\
\hline 7 & 518 & 3.58 & 548 & $0.53 \pm 0.04$ & $-d$ \\
\hline 8 & 554 & 4.31 & 590 & $0.41 \pm 0.03$ & $0.07 \pm 0.01$ \\
\hline 9 & 561 & 5.06 & 616 & $0.11 \pm 0.02$ & $0.032 \pm 0.004$ \\
\hline 10 & 562 & 5.36 & 617 & $0.15 \pm 0.01$ & $-d$ \\
\hline
\end{tabular}

${ }^{a}$ Determined from three independent measurements. ${ }^{b}$ Determined by irradiation at $525 \mathrm{~nm}$ (compounds 3 and 4 ) and $545 \mathrm{~nm}$ (compound 8); 1,3-diphenylisobenzofuran (DPBF) was used as a singlet oxygen trap; rose bengal was used as a reference sensitizer [46]. ${ }^{c}$ Determined by irradiation at $490 \mathrm{~nm}$ using DPBF as a singlet oxygen trap and compound 3 as a reference. ${ }^{d}$ Not measured.

Table 2. Photophysical and photochemical properties of meso-Carboxy BODIPY derivatives in PBS/DMSO mixtures ${ }^{a}$.

\begin{tabular}{|c|c|c|c|c|c|c|}
\hline Compound & $\lambda_{\max }^{\mathrm{abs}} / \mathrm{nm}$ & $\varepsilon / 10^{4} \mathrm{M}^{-1} \mathrm{~cm}^{-1}$ & $\lambda_{\max }^{\mathrm{em}} / \mathrm{nm}$ & $\Phi_{\mathrm{f}}^{b}$ & $\Phi_{\mathrm{r}} / 10^{-4 c}$ & $(\mathrm{CO}) / \%^{h}$ \\
\hline 2 & 497 & 4.35 & 507 & $0.58 \pm 0.02$ & $\begin{array}{l}4.1 \pm 0.04^{d} \\
5.2 \pm 0.06^{e}\end{array}$ & $\begin{array}{c}7^{i} \\
15^{j}\end{array}$ \\
\hline 3 & 521 & 5.20 & 563 & $0.13 \pm 0.01$ & $\begin{array}{l}58.4 \pm 0.7^{d} \\
68.2 \pm 0.05^{e}\end{array}$ & $\begin{array}{c}8^{i} \\
18^{j}\end{array}$ \\
\hline 4 & 528 & 5.04 & 548 & $0.012 \pm 0.001$ & $-k$ & $\begin{array}{l}10^{i} \\
7^{j}\end{array}$ \\
\hline 5 & 500 & 4.65 & 510 & $0.23 \pm 0.01$ & $-{ }^{k}$ & $\begin{array}{l}5^{i} \\
7^{j}\end{array}$ \\
\hline 6 & 484 & 3.82 & 500 & $0.072 \pm 0.001$ & $-{ }^{k}$ & $\begin{array}{l}13^{i} \\
8^{j}\end{array}$ \\
\hline 7 & 522 & 4.78 & 556 & $0.49 \pm 0.03$ & $-k$ & $\begin{array}{l}6^{i} \\
7^{j}\end{array}$ \\
\hline 8 & 558 & 4.13 & 603 & $0.13 \pm 0.01$ & $\begin{array}{l}0.70 \pm 0.02^{f} \\
1.30 \pm 0.06^{g}\end{array}$ & $\begin{array}{l}19^{i} \\
32^{j}\end{array}$ \\
\hline 9 & 564 & 3.17 & 637 & $0.020 \pm 0.002$ & $\begin{array}{l}0.57 \pm 0.05^{f} \\
0.78 \pm 0.01^{g}\end{array}$ & $\begin{array}{l}16^{i} \\
44^{j}\end{array}$ \\
\hline 10 & 565 & 3.95 & 633 & $0.067 \pm 0.005$ & $\begin{array}{l}0.20 \pm 0.01^{f} \\
0.80 \pm 0.03^{g}\end{array}$ & $\begin{array}{l}24^{i} \\
43^{j}\end{array}$ \\
\hline
\end{tabular}

${ }^{a}$ Measured in PBS $(I=0.1 \mathrm{M}, \mathrm{pH}=7.4) / \mathrm{DMSO}\left(2-7,90: 10 ;\right.$ 8-10, 80:20) mixtures. ${ }^{b}$ Determined from three independent measurements. ${ }^{c}$ Quantum yields of photochemical degradation determined by irradiation at $525 \mathrm{~nm}$ using meso-carboxy BODIPY derivative 22 [47] (see the Experimental section) as an actinometer in ${ }^{d}$ aerated or ${ }^{e}$ degassed PBS/DMSO mixtures $(90: 10, v / v ; I=0.1 \mathrm{M}, \mathrm{pH}=7.4)$ or in ${ }^{f}$ aerated or ${ }^{g}$ degassed PBS/DMSO mixtures $(80: 20, v / v ; I=0.1 \mathrm{M}, \mathrm{pH}=7.4) .{ }^{h}$ Maximum chemical yields of the CO photoproduction in ${ }^{i}$ aerated or ${ }^{j}$ degassed PBS $(I=0.1 \mathrm{M}, \mathrm{pH}=7.4) / \mathrm{DMSO}(\mathbf{2}, \mathbf{7}, \mathbf{8}, \mathbf{1 0}, 99: 1 ; 3-6,90: 10 ; 9,80: 20)$ mixtures upon irradiation at $\lambda_{\text {max }}^{\text {abs }}{ }^{k}$ Not measured.

Time-resolved spectroscopy: We performed nanosecond transient absorption (TA) spectroscopy of selected BODIPY derivatives in both aerated and degassed PBS/DMSO mixtures $\left(\mathrm{c} \sim 10^{-5} \mathrm{M} ; \lambda_{\text {exc }}=532 \mathrm{~nm}\right)$ to identify long-lived intermediates. Derivatives 3 and 4 gave strong transient signals with $\lambda_{\max }$ at $\approx 436 \mathrm{~nm}$ (Figures S102-S111). A prominent ground state bleach with $\lambda_{\max }=506$ and $530 \mathrm{~nm}$ (Figures S102, S103, S107 and S108) for 3 and 4, respectively, was also observed. The kinetic traces were fitted to a first-order rate law (the oxygen concentration in an aerated solution at $20^{\circ} \mathrm{C}\left(\sim 2.7 \times 10^{-4} \mathrm{M}[48]\right)$ was almost 30 times higher than that of a BODIPY derivative) to provide the lifetimes of $320 \mathrm{~ns}$ and $25 \mu$ s for 3 and 256 ns and $11.40 \mu$ s for 4 in aerated and degassed solutions, respectively (Table S1), which is in good agreement with the lifetimes reported for analogous BODIPY systems [36]. We assigned these signals to the triplet states [49]. Derivatives 2 and 7 did not show any apparent signals in the range typical for the triplet-excited BODIPYs; 
only fluorescence and ground-state bleach signals were detected (Figures S100, S101, S112 and S113); thus, triplet state concentrations were below the detection limit of our TA spectroscopy setup.

Intersystem crossing efficiency and singlet oxygen production: As the photochemical release of CO from meso-carboxy BODIPYs was reported to occur from the triplet-excited state [36], we evaluated the ISC efficiency $\left(\Phi_{\text {ISC }}\right)$ by quantitative analysis of the transient optical density $[50,51]$ using nanosecond TA spectroscopy. Triplet state transient signals of 3 and 4 in methanol were sufficiently strong to obtain the $\Phi_{\text {ISC }}$ values of 0.66 and 0.83 , respectively. Besides, we evaluated quantum yields of the singlet oxygen production $\left(\Phi_{\Delta}\right)$ for selected derivatives in methanol using 1,3-diphenylisobenzofuran (DPBF) as a ${ }^{1} \mathrm{O}_{2}$ trap (Table 1). The high $\Phi_{\Delta}$ values of 0.59 and 0.72 for 3 and 4 (Figures S95 and S96), respectively, bearing heavy halogen atoms directly attached to the BODIPY core, match those of analogous BODIPY derivatives with halogen or chalcogen atoms in various core positions $[8,11,14,15]$. These values are only slightly lower than those of $\Phi_{\text {ISC }}$, thus $\Phi_{\Delta}$ can be used advantageously to estimate the lower limit of $\Phi_{\text {ISC }}$. As anticipated, a small $\Phi_{\Delta}$ was found for compounds 2, 5, 6, 8, and 9 (Figures S97 and S98).

Photorelease of $\mathrm{CO}$ : We evaluated the quantum yields of photochemical degradation $\left(\Phi_{\mathrm{r}}\right)$ of selected derivatives in a PBS/DMSO mixture (Table 2). In all cases, the efficiencies were greater in the absence of oxygen because of quenching of the reactive triplet state. Besides, the $\Phi_{\mathrm{r}}$ value for $3\left(58 \times 10^{-4}\right)$ was larger than that of 8 by two orders of magnitude $\left(0.7 \times 10^{-4}\right)$, indicating that the triplet state is considerably more photochemically active, as previously discussed [36]. Because the efficiency of photodegradation of all BODIPY derivatives in methanol was too low (irradiation of 8 in methanol under the same conditions led to a $\approx 5 \%$ conversion in $12 \mathrm{~h}$, for example), we have not investigated their photochemistry in this solvent in detail.

Compounds $\mathbf{2 - 1 0}$ in PBS/DMSO mixtures were found to produce different amounts of CO upon irradiation at the corresponding $\lambda_{\max }^{\text {abs }}$ (Table 2; Figure 2 and Figures S77-S94). The chemical yields obtained upon exhaustive photolysis were rather small for BODIPYs 2-7 ( $<15 \%)$ but considerably higher for phenethynyl derivatives 8-10 (up to 45\% upon complete conversion in a degassed solvent). As expected (see above), the yields dropped approximately by half in aerated solutions. However, compounds 3 and 4 with an enhanced ISC, which could promote a more efficient CO release from the triplet state [36], did not liberate $\mathrm{CO}$ in high yields. Besides, lower chemical yields of $\mathrm{CO}$ found in degassed rather than aerated solutions for compounds 4 and 6 (Table 2) suggest that at least one of the competing degradation pathways is independent of the presence of oxygen.

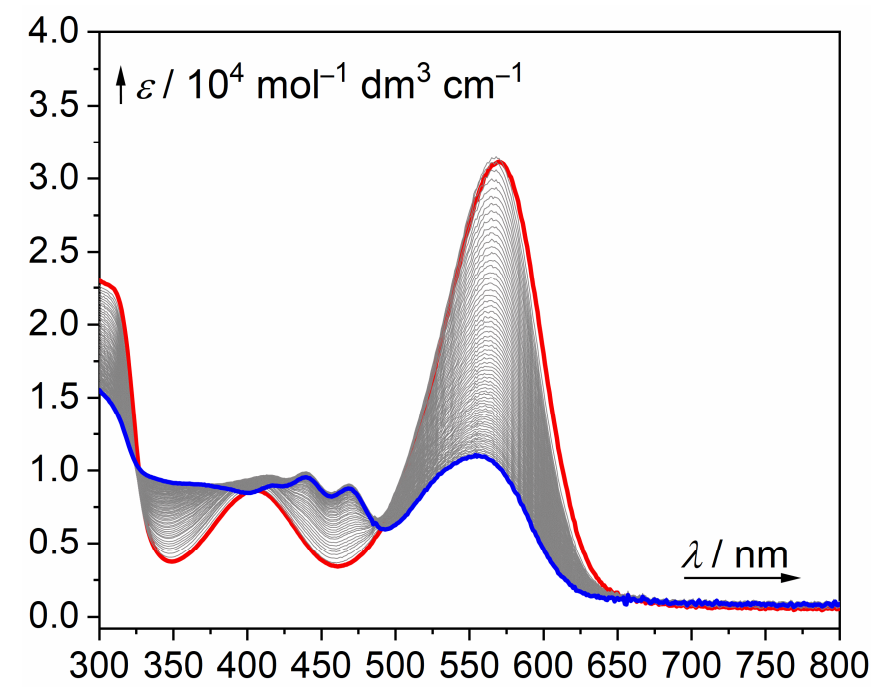

Figure 2. Irradiation of 10 in a degassed PBS/DMSO mixture (80:20, v/v) at $545 \mathrm{~nm}$ for $12 \mathrm{~h}$ (red line: the initial spectrum; blue line: the end spectrum). 
Therefore, we analyzed the photoproducts formed upon irradiation of $\mathbf{1 0}$ in a PBS/DMSO mixture by high-resolution mass spectra (HRMS). Based on the proposed photoproduct structures (Supplementary Materials), we suggest that the CO production competes with bleaching of the starting material with the generated singlet oxygen [36] (for example, by oxidative cleavage of the triple bond or ring opening of the BODIPY core, reported before in [52]), or the compound undergoes a photoinduced attack of water as a nucleophile at position 3 [53] or an exchange of fluorine(s) by the $\mathrm{OH}$ group(s). Figure 2 shows that a photoproduct formed upon irradiation of 10, characterized by a slight hypsochromic shift of the main absorption band, is further consumed upon continuing irradiation. Because the absorption maximum of this intermediate is similar to that of the starting material, the compound must still retain a BODIPY or BODIPY-like chromophore (Supplementary Materials).

The introduction of an electron-withdrawing group (6) or an additional carboxy group (5) at position 2 did not improve the $\mathrm{CO}$ yields. According to the proposed mechanism of the CO release from meso-carboxy BODIPYs $\mathbf{1 a}, \mathbf{b}$ (Scheme 1), electron-withdrawing groups should enhance electron transfer from the carboxylate (with $\mathrm{p} K_{\mathrm{a}}$ of $\approx 4.7$ [36]; the acids are fully dissociated at $\mathrm{pH}=7.4$ ) to the triplet-excited BODIPY core. However, we could not verify this hypothesis because the competing dye degradation in both the presence and absence of oxygen was more efficient than the $\mathrm{CO}$ release. A low $\mathrm{CO}$ yield in 2 was also unexpected because analogous BODIPY derivatives with the unsubstituted 1,7-positions (1, Scheme 1) were reported to liberate $\mathrm{CO}$ in up to $87 \%$ yields in degassed solutions [36]. The methyl substituents at positions 2 and 6, which were introduced to improve the stability in the dark (Figures S74-S76) and simplify the synthesis of meso-carboxy BODIPYs, thus must play a detrimental role in the $\mathrm{CO}$ photorelease. This behavior may be related to an out-ofplane geometry of the BODIPY core induced by the steric hindrance of a meso-substituent and the 1,7-dimethyl groups that are responsible for a more efficient nonradiative decay via "butterfly motion" discussed for analogous substituted BODIPY derivatives [24,54].

Fortunately, $\pi$-extended derivatives 8-10 not only provided improved chemical yields of the $\mathrm{CO}$ formation but their absorption bands were bathochromically shifted toward the biologically desired longer wavelengths. Compounds $\mathbf{8}$ and water-soluble $\mathbf{1 0}$ were therefore selected for the assessment of the cellular cytotoxicity before their use in further biological studies.

Cellular toxicity: To determine the cellular toxicity of compounds $\mathbf{8}$ and $\mathbf{1 0}$ and their corresponding photoproducts, an MTT test was used to assess cell viability on the human hepatoblastoma HepG2 cell line. HepG2 cells were incubated with selected photoCORMs or their respective photoproducts for 2, 6, and $24 \mathrm{~h}$. Compound 8 displayed no cytotoxicity within the concentration range of $12.5-100 \mu \mathrm{mol} \mathrm{L}^{-1}$ (Figure S116), whereas compound 10 showed no effects on cell viability up to the concentration of $50 \mu \mathrm{mol} \mathrm{L}^{-1}$ (Figure S117). Their photoproducts were found to be non-cytotoxic in the concentration range of $12.5-200 \mu \mathrm{mol} \mathrm{L}{ }^{-1}$ (Figures S117 and 118). These cytotoxicity data are comparable to those observed for meso-carboxy BODIPY photoCORMs 1a, b (Scheme 1) [36].

\section{Experimental Section}

Materials: Reagents and solvents of the highest purity available were used as purchased, or they were purified/dried using the standard methods when necessary.

Methods: The lowest possible intensity of incident light was used in the spectroscopic identification of the samples to prevent their photodegradation. All measurements were accomplished using fresh solutions prepared in the dark. ${ }^{1} \mathrm{H}$ and ${ }^{13} \mathrm{C} \mathrm{NMR}$ spectra were obtained in $\mathrm{CDCl}_{3}, \mathrm{CD}_{2} \mathrm{Cl}_{2}$, DMSO- $d_{5}$, or $\mathrm{CD}_{3} \mathrm{OD}$ on $75,125,300$, and $500 \mathrm{MHz}$ spectrometers (Bruker AVANCE III (300 MHz) and AVANCE III HD (500 MHz) spectrometers). ${ }^{1} \mathrm{H}$ chemical shifts are reported in ppm relative to the tetramethylsilane signal (TMS, $\delta=0.00 \mathrm{ppm}$ ) using the residual solvent signal as an internal reference. ${ }^{13} \mathrm{C} \mathrm{NMR}$ chemical shifts are reported in ppm relative to the solvent signal as an internal standard. High-resolution mass spectra (HRMS) were recorded on an Agilent 6224 Accurate-Mass 
TOF LC-MS instrument using ESI or APCl techniques. Absorption spectra and the molar absorption coefficients were obtained on a UV-vis spectrometer with matched 1.0 or $0.1 \mathrm{~cm}$ quartz cells. Molar absorption coefficients were determined from the absorption spectra; the average values were obtained from three independent measurements with solutions of different concentrations. No dependence of the molar absorption coefficient on the sample concentration was observed in the range from $1 \times 10^{-4}$ to $1 \times 10^{-6} \mathrm{M}$. All glassware was oven-dried before use. Purification procedures were performed using silica gel (Merck 60; 230-400 mesh) columns or by recrystallization.

Determination of CO yields: A solution of compounds 2-10 (100-10 mM) in a PBS $(I=0.1 \mathrm{M}, \mathrm{pH} \approx 7.4)$ /DMSO solution was irradiated with LEDs emitting at the corresponding wavelengths $\left(\lambda_{\max }=490,525\right.$, or $\left.545 \mathrm{~nm}\right)$ in closed GC vials fitted with PTFE septa to complete the conversion of the starting material. The released $\mathrm{CO}$ into the vial headspace was determined by a GC-Agilent 5973 Mass Selective Detector headspace technique, which was calibrated using the photoreaction of cyclopropenone photoCORM [55] (50-500 $\mu \mathrm{L}$, $c \approx 5 \times 10^{-4} \mathrm{M}$, in methanol).

Decomposition quantum yields: The quantum yields of the decomposition of BODIPY derivatives in both aerated and degassed (purged with argon for 20 min) PBS/DMSO solutions were determined at $\lambda_{\text {irr }}=525 \mathrm{~nm}$ (LEDs) using the BODIPY derivative 22 [36] as an actinometer dissolved in PBS $(I=0.1 \mathrm{M}, \mathrm{pH}=7.4)$ according to the published procedure [36]. All quantum yield measurements were repeated five times with independently prepared samples.

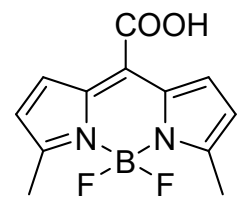

22

Singlet oxygen production quantum yields: Quantum yields for the singlet oxygen production, sensitized by BODIPYs derivatives in methanol at 525 (compounds 2, 3 and 4), 490 (compounds 5 and 6), and $545 \mathrm{~nm}$ (compounds 8 and 9), were determined by monitoring the photooxidation of 1,3-diphenylisobenzofuran (DPBF) using rose bengal (RB) [46] as a reference sensitizer. For derivatives 5 and 6, compound 3 was used as a reference. A solution of $\operatorname{DPBF}\left(c=5 \times 10^{-5}\right)$ and either $\operatorname{BODIPY}\left(c=1 \times 10^{-5} \mathrm{M}\right)$ or RB $\left(c=5 \times 10^{-6} \mathrm{M}\right)$ sensitizers in methanol was prepared. The stirred solution $(3 \mathrm{~mL})$ in a $1 \mathrm{~cm}$ quartz cell was irradiated using LEDs at a selected wavelength, and the UV-vis spectra were recorded periodically. The irradiation time was chosen to reach approximately $10 \%$ conversion of DPBF. The procedure was repeated five times.

Fluorescence quantum yields: Fluorescence quantum yields were determined on an Edinburg Instrument FLS920 fluorimeter as the absolute values using an integrating sphere. The quantum yields were measured three times and were averaged for each sample. The solution concentrations were kept low $(A<0.1)$. The fluorescence quantum yields were determined in methanol or a PBS $(\mathrm{pH}=7.4,10 \mathrm{mM}, \mathrm{I}=0.1 \mathrm{M}) / \mathrm{DMSO}$ mixture.

Transient spectroscopy: The nanosecond laser flash spectroscopy setup was generally operated in a right-angle arrangement of the pump and probe beams. Laser pulses of $\leq 170$ ps or 700 ps duration at $532 \mathrm{~nm}(20-240 \mathrm{~mJ})$ were obtained from an Nd:YAG laser. The laser beam was dispersed onto a $40 \mathrm{~mm}$ long and $10 \mathrm{~mm}$ wide modified fluorescence cuvette held in a laying arrangement. An overpulsed Xe arc lamp was used as a source of the probe light. Kinetic traces were recorded using a photomultiplier. Transient absorption spectra were obtained using an ICCD camera equipped with a spectrograph. The samples were degassed by three freeze-pump-thaw cycles under reduced pressure (0.01 Torr). Absorption spectra of the sample solutions were measured regularly between laser flashes to test for possible photodegradation of the solution components using a diode-array spectrophotometer [56]. 
Intersystem crossing quantum yield: The ISC efficiency $\left(\Phi_{\text {ISC }}\right)$ was evaluated by a quantitative analysis of the transient optical density (see Supplementary Materials for details) $[50,51]$ using nanosecond TA spectroscopy for selected derivatives in degassed methanol solutions (three freeze-pump-thaw cycles) at three different concentrations $\left(3.0,6.0\right.$, and $\left.10.0 \times 10^{-6} \mathrm{M}\right)$.

Cellular toxicity experiments: Human hepatobastoma HepG2 cell line (ATCC, Manassas, VA, USA) was used to test the cytotoxicity. The cells were grown in supplemented MEM media in 96-well plates according to the manufacturer's instructions. The cells were kept at $37{ }^{\circ} \mathrm{C}$ and $5 \% \mathrm{CO}_{2}$ atmosphere during the experiment. The stock solution was prepared by dissolving a BODIPY derivative in DMSO; the final solutions were prepared by dissolution of stock solutions with Minimal Essential Medium (MEM). The final concentration of DMSO in media did not exceed $1 \%$. The corresponding photoproducts were prepared by exhaustive irradiation of the solutions at $\lambda_{\text {irr }}=505 \mathrm{~nm}$ for $24 \mathrm{~h}$. Viability was determined using an MTT test (colorimetric assay based on the reduction of a yellow tetrazolium salt (3-(4,5-dimethylthiazol-2-yl)-2,5-diphenyltetrazolium bromide) as described before [57]. All experiments were performed at least in triplicates.

\section{Synthesis}

4,4'-Difluoro-8-methoxycarbonyl-1,3,5,7-tetramethyl-4-bora-3a,4a-diaza-s-indacene (11). This compound was prepared using a slightly modified procedure described in the literature [37]. 2,4-Dimethylpyrrole ( $1 \mathrm{~mL}, 9.71 \mathrm{mmol}, 2.5$ equiv.) in dry dichloromethane $(10 \mathrm{~mL})$ was added dropwise to the solution of methyl oxochlorooxalate $(0.36 \mathrm{~mL}, 3.88 \mathrm{mmol}$, 1 equiv.) in dry dichloromethane $(25 \mathrm{~mL})$ at room temperature under nitrogen atmosphere. The reaction mixture was stirred at $22{ }^{\circ} \mathrm{C}$ for $4 \mathrm{~h}$ and then cooled to $0{ }^{\circ} \mathrm{C}$. Triethylamine (2.70 mL, $19.4 \mathrm{mmol}, 5$ equiv.) and, after $5 \mathrm{~min}, \mathrm{BF}_{3} \cdot \mathrm{Et}_{2} \mathrm{O}(46 \%, 5.22 \mathrm{~mL}, 19.4 \mathrm{mmol}$, 5 equiv.) were added. The reaction mixture was stirred at $22{ }^{\circ} \mathrm{C}$ for $8 \mathrm{~h}$. Aq. $\mathrm{HCl}(10 \%$, $50 \mathrm{~mL}$ ) was added, and the crude mixture was extracted with dichloromethane $(3 \times 40 \mathrm{~mL})$. The collected organic layers were dried over anhydrous magnesium sulfate, filtered, and concentrated to dryness under reduced pressure. The product was purified by flash chromatography on silica gel (cyclohexane/dichloromethane, 7:3) and recrystallization from hexane containing a small amount of dichloromethane. Yield $0.400 \mathrm{~g}$ (34\%). Orange solid. The spectroscopic data are in good agreement with those from the literature [37]. ${ }^{1} \mathrm{H}$ NMR $\left(300 \mathrm{MHz} \mathrm{CDCl}_{3}\right): \delta(\mathrm{ppm}) 6.07(\mathrm{~s}, 2 \mathrm{H}), 3.98(\mathrm{~s}, 3 \mathrm{H}), 2.54(\mathrm{~s}, 6 \mathrm{H}), 2.13(\mathrm{~s}, 6 \mathrm{H})$ (Figure S1). ${ }^{13} \mathrm{C} \mathrm{NMR}\left(75 \mathrm{MHz}, \mathrm{CDCl}_{3}\right): \delta$ (ppm) 165.7, 157.6, 141.0, 128.8, 128.7, 121.2, 53.0, 14.7, 12.5 (Figure S21). HRMS-APCl ${ }^{+} \mathrm{m} / z$ : $[\mathrm{M}+\mathrm{H}]^{+}$calculated for $\mathrm{C}_{15} \mathrm{H}_{18} \mathrm{BF}_{2} \mathrm{~N}_{2} \mathrm{O}_{2}$ 307.1427, found 307.1426 (Figure S39).

8-Benzyloxycarbonyl-4,4'-difluoro-1,3,5,7-tetramethyl-4-bora-3a,4a-diaza-s-indacene (12). This compound was prepared according to the literature [37]. Benzyl alcohol (10.8 g, $100 \mathrm{mmol}, 1$ equiv.) in dry dichloromethane $(8 \mathrm{~mL})$ was added through a syringe pump to a solution of oxalyl chloride ( $12.7 \mathrm{~g}, 100 \mathrm{mmol}, 1$ equiv.) in anhydrous dichloromethane $(50 \mathrm{~mL})$ over $0.5 \mathrm{~h}$. The solvent was removed under reduced pressure, affording benzyl chlorooxalate as colorless oil. The solution of previously generated benzyl chlorooxalate ( $2 \mathrm{~g}, 10.1 \mathrm{mmol}, 1$ equiv.) in anhydrous dichloromethane $(20 \mathrm{~mL})$ was added dropwise to the solution of 2,4-dimethylpyrrole ( $2.4 \mathrm{~g}, 25.4 \mathrm{mmol}, 2.5$ equiv.) in dry dichloromethane $(20 \mathrm{~mL})$ through a syringe pump over $1 \mathrm{~h}$ at $-78^{\circ} \mathrm{C}$ under argon atmosphere. The resulting mixture was stirred at this temperature for $4 \mathrm{~h}$, and cooled to $0{ }^{\circ} \mathrm{C}$. Then, triethylamine (5.6 mL, $57.2 \mathrm{mmol}, 5.7$ equiv.) was added dropwise. After $5 \mathrm{~min}, \mathrm{BF}_{3} \cdot \mathrm{Et}_{2} \mathrm{O}(8.0 \mathrm{~mL}$, $64.8 \mathrm{mmol}, 6.5$ equiv.) was added, and the solution was warmed slowly to room temperature and stirred overnight. After removing the solvent under reduced pressure, the residue was purified by column chromatography (dichloromethane/hexane, 1:6 to 1:2). Yield: $1.2 \mathrm{~g} \mathrm{(31 \% ).} \mathrm{Red} \mathrm{solid.} \mathrm{The} \mathrm{spectroscopic} \mathrm{data} \mathrm{are} \mathrm{in} \mathrm{good} \mathrm{agreement} \mathrm{with} \mathrm{those}$ from the literature [37]. ${ }^{1} \mathrm{H} \mathrm{NMR}\left(300 \mathrm{MHz} \mathrm{CDCl}_{3}\right): \delta(\mathrm{ppm}) 7.43-7.38(\mathrm{~m}, 5 \mathrm{H}), 6.03$ (s, 2H), 5.39 (s, 2H), $2.52(\mathrm{~s}, 6 \mathrm{H}), 2.02(\mathrm{~s}, 6 \mathrm{H})$ (Figure S2). ${ }^{13} \mathrm{C} \mathrm{NMR}\left(75 \mathrm{MHz}, \mathrm{CDCl}_{3}\right): \delta(\mathrm{ppm})$ 
165.2, 157.8, 141.3, 133.8, 129.3, 129.2, 128.9, 121.3, 68.7, 14.9, 12.8 (Figure S22). HRMS-APCl ${ }^{-}$ $\mathrm{m} / z$ : $[\mathrm{M}]^{-}$calculated for $\mathrm{C}_{21} \mathrm{H}_{21} \mathrm{BF}_{2} \mathrm{~N}_{2} \mathrm{O}_{2} 382.1664$, found 382.1671 (Figure S40).

8-Benzyloxycarbonyl-4,4'-difluoro-1,3,5,7-tetramethyl-2-oxo-4-bora-3a,4a-diaza-s-indacene (13). Dry DMF (6.0 mL, $135.0 \mathrm{mmol}, 128$ equiv.) was submitted in a dry schlenk flask and cooled down to $0{ }^{\circ} \mathrm{C}$. $\mathrm{POCl}_{3}(6.0 \mathrm{~mL}, 37.1 \mathrm{mmol}, 35$ equiv. $)$ was slowly added at $0{ }^{\circ} \mathrm{C}$ and the solution was stirred for 5 min under intensive stirring. The ice bath was removed, and the solution was stirred at room temperature for $30 \mathrm{~min}$. BODIPY $12(0.4 \mathrm{~g}, 1.05 \mathrm{mmol}$, 1 equiv.) dissolved in dry dichloroethane $(25 \mathrm{~mL})$ was added to the solution. The resulting mixture was stirred for $2 \mathrm{~h}$ at $50{ }^{\circ} \mathrm{C}$ under argon atmosphere. The reaction mixture was cooled to room temperature and slowly poured into saturated aqueous $\mathrm{NaHCO}_{3}$ $(200 \mathrm{~mL})$ under ice-cold conditions. After being warmed to room temperature, the reaction mixture was further stirred for $30 \mathrm{~min}$ and washed with water $(2 \times 150 \mathrm{~mL})$. The organic layers were combined, dried over anhydrous magnesium sulfate, and evaporated under reduced pressure. The crude product was further purified by column chromatography (dichloromethane/hexane, 2:1). Yield $0.17 \mathrm{~g}(40 \%)$. Dark red solid. ${ }^{1} \mathrm{H}$ NMR (300 MHz, $\left.\mathrm{CDCl}_{3}\right): \delta(\mathrm{ppm}) 10.04(\mathrm{~s}, 1 \mathrm{H}), 7.43-7.38(\mathrm{~m}, 5 \mathrm{H}), 6.21(\mathrm{~s}, 1 \mathrm{H}), 5.42(\mathrm{~s}, 2 \mathrm{H}), 2.78(\mathrm{~s}, 3 \mathrm{H}), 2.59$ $(\mathrm{s}, 3 \mathrm{H}), 2.31(\mathrm{~s}, 3 \mathrm{H}), 2.07(\mathrm{~s}, 3 \mathrm{H})$ (Figure S3). ${ }^{13} \mathrm{C} \mathrm{NMR}\left(125 \mathrm{MHz}, \mathrm{CDCl}_{3}\right): \delta(\mathrm{ppm})$ 185.6, 164.3, 157.9, 145.3, 140.7, 133.1, 132.0, 130.4, 129.4, 129.4, 128.9, 126.9, 126.0, 124.2, 69.1, 15.4, 13.04, 13.0, 12.3 (Figure S23). HRMS-APCl ${ }^{-} \mathrm{m} / \mathrm{z}:[\mathrm{M}-\mathrm{H}]^{-}$calculated for $\mathrm{C}_{22} \mathrm{H}_{20} \mathrm{BF}_{2} \mathrm{~N}_{2} \mathrm{O}_{3}$ 409.1545, found 409.1544 (Figure S41).

8-Benzyloxycarbonyl-2-carboxyl-4,4'-difluoro-1,3,5,7-tetramethyl-4-bora-3a,4a-diazas-indacene (14). To 13 (0.15 g, $0.36 \mathrm{mmol}, 1$ equiv.) in mixed solution of THF (15 mL) and water $(7 \mathrm{~mL}), \mathrm{NaClO}_{2}(0.33 \mathrm{~g}, 3.66 \mathrm{mmol}, 10$ equiv. $)$ and $\mathrm{NH}_{2} \mathrm{SO}_{3} \mathrm{H}(0.36 \mathrm{~g}, 3.66 \mathrm{mmol}$, 10 equiv.) were added. The mixture was stirred at room temperature for $2 \mathrm{~h}$. Then the mixture was diluted with ethyl acetate and washed with aqueous $\mathrm{Na}_{2} \mathrm{~S}_{2} \mathrm{O}_{3}$. The organic layers were combined, dried over anhydrous magnesium sulfate, and evaporated under reduced pressure. The crude product was further purified by column chromatography (silica gel; hexane/ethyl acetate, 4:1 to 1:1) to give compound 14. Yield $0.085 \mathrm{~g}(55 \%)$. Dark red solid. ${ }^{1} \mathrm{H}$ NMR $(300 \mathrm{MHz}$, DMSO-d5): $\delta(\mathrm{ppm}) 12.71$ (bs, 1H), 7.52-7.42 (m, 5H), $6.50(\mathrm{~s}$, $1 \mathrm{H}), 5.51(\mathrm{~s}, 2 \mathrm{H}), 2.65(\mathrm{~s}, 3 \mathrm{H}), 2.50(\mathrm{~s}, 3 \mathrm{H}$, solvent peak), $2.23(\mathrm{~s}, 3 \mathrm{H}), 2.07(\mathrm{~s}, 3 \mathrm{H})$ (Figure $\mathrm{S} 4)$. ${ }^{13} \mathrm{C}$ NMR (125 MHz, DMSO-d5): $\delta$ (ppm) 165.0, 163.8, 163.0, 156.8, 144.3, 141.1, 133.5, 130.1, 129.7, 129.6, 129.1, 128.7, 125.8, 124.2, 69.1, 14.9, 14.4, 12.6, 11.2 (Figure S24). HRMS-APCl ${ }^{-}$ $m / z:[\mathrm{M}]^{-}$calculated for $\mathrm{C}_{22} \mathrm{H}_{21} \mathrm{BF}_{2} \mathrm{~N}_{2} \mathrm{O}_{4} 426.1566$, found 426.1569 (Figure S42).

8-Benzyloxycarbonyl-4,4'-difluoro-2-hydroxyimino-1,3,5,7-tetramethyl-4-bora-3a,4a-diazas-indacene (15). BODIPY 13 (0.13 g, $0.31 \mathrm{mmol}, 1$ equiv.) was added to the solution of hydroxylamine hydrochloride $(0.22 \mathrm{~g}, 3.17 \mathrm{mmol}, 10$ equiv. $)$ and sodium hydroxide $(0.12 \mathrm{~g}$, $3.17 \mathrm{mmol}, 10$ equiv.) in ethanol $(10 \mathrm{~mL})$ by a syringe pump within $30 \mathrm{~min}$. The mixture was then heated at $60^{\circ} \mathrm{C}$ for $4 \mathrm{~h}$. The resulting mixture was diluted with ethyl acetate and washed by using water and brine. The organic layer was collected, dried over anhydrous magnesium sulfate, filtered, and concentrated under reduced pressure. The residue was purified by column chromatography (hexane/ethyl acetate/dichloromethane, 7:2:1). Yield $0.070 \mathrm{~g}(52 \%)$. Purple powder. ${ }^{1} \mathrm{H}$ NMR $\left(300 \mathrm{MHz}, \mathrm{CDCl}_{3}\right): \delta(\mathrm{ppm}) 8.13(\mathrm{~s}, 1 \mathrm{H})$, 7.46-7.39 (m, 5H), $6.12(\mathrm{~s}, 1 \mathrm{H}), 5.42(\mathrm{~s}, 2 \mathrm{H}), 2.68(\mathrm{~s}, 3 \mathrm{H}), 2.57(\mathrm{~s}, 3 \mathrm{H}), 2.14(\mathrm{~s}, 3 \mathrm{H}), 2.07(\mathrm{~s}, 3 \mathrm{H})$ (Figure S5). This intermediate was subsequently used in the next reaction without further purification.

8-Benzyloxycarbonyl-2-cyano-4,4'-difluoro-1,3,5,7-tetramethyl-4-bora-3a,4a-diaza-s- indacene (16). BODIPY 15 (0.07 g, $0.16 \mathrm{mmol}, 1$ equiv. $)$ was treated with oxalyl chloride $(0.21 \mathrm{~g}, 1.65 \mathrm{mmol}, 10$ equiv.) in acetonitrile $(20 \mathrm{~mL})$ under reflux for $4 \mathrm{~h}$. The mixture was diluted with ethyl acetate and washed with saturated aqueous $\mathrm{NaHCO}_{3}$. The organic layers were collected, dried over anhydrous magnesium sulfate, filtered, and concentrated under reduced pressure. The residue was purified by column chromatography (hexane/ethyl acetate/dichloromethane, 7:2:1). Yield $0.052 \mathrm{~g}$, 78\%). Red powder. ${ }^{1} \mathrm{H}$ NMR (300 MHz, $\left.\mathrm{CDCl}_{3}\right): \delta(\mathrm{ppm}) 7.47-7.41(\mathrm{~m}, 5 \mathrm{H}), 6.23(\mathrm{~s}, 1 \mathrm{H}), 5.44(\mathrm{~s}, 2 \mathrm{H}), 2.64(\mathrm{~s}, 3 \mathrm{H}), 2.61(\mathrm{~s}, 3 \mathrm{H}), 2.13$ 
$(\mathrm{s}, 3 \mathrm{H}), 2.07(\mathrm{~s}, 3 \mathrm{H})$ (Figure $\mathrm{S6})$. This intermediate was subsequently used in the next reaction without further purification.

4,4'-Difluoro-2,6-diiodo-8-methoxycarbonyl-1,3,5,7-tetramethyl-4-bora-3a,4a-diaza-sindacene (17). ICl solution (1 $\mathrm{M}$ in dichloromethane, $0.98 \mathrm{~mL}, 0.98 \mathrm{mmol}$, 2.5 equiv.) was added to a solution of BODIPY $11(0.150 \mathrm{~g}, 0.39 \mathrm{mmol}, 1$ equiv. $)$ in dry dichloromethane $(30 \mathrm{~mL})$ at room temperature under a nitrogen atmosphere, and the reaction mixture was stirred at $22{ }^{\circ} \mathrm{C}$ for $45 \mathrm{~min}$. Water was added, and the mixture was extracted with dichloromethane $(3 \times 20 \mathrm{~mL})$. The collected organic layers were dried over anhydrous magnesium sulfate, filtered, and concentrated to dryness under reduced pressure. The product was purified by flash chromatography on silica gel (cyclohexane/dichloromethane, 8:2) and recrystallization from hexane containing a small amount of dichloromethane. Yield $0.200 \mathrm{~g}(91 \%)$. Purple solid. ${ }^{1} \mathrm{H}$ NMR $\left(300 \mathrm{MHz}, \mathrm{CDCl}_{3}\right): \delta(\mathrm{ppm}) 4.01(\mathrm{~s}, 3 \mathrm{H}), 2.63(\mathrm{~s}, 6 \mathrm{H})$, 2.14 (s, 6H) (Figure S7). ${ }^{13} \mathrm{C}$ NMR (75 MHz, $\mathrm{CDCl}_{3}$ ): $\delta$ (ppm) 165.2, 158.8, 143.4, 128.4, 128.2, 85.5, 53.5, 16.1, 15.1 (Figure S25). $\mathrm{HRMS}_{-\mathrm{APCl}^{+}} \mathrm{m} / \mathrm{z}$ : $[\mathrm{M}+\mathrm{H}-\mathrm{HF}]^{+}$calculated for $\mathrm{C}_{15} \mathrm{H}_{15} \mathrm{BFI}_{2} \mathrm{~N}_{2} \mathrm{O}_{2}$ 538.9297, found 538.9294 (Figure S43).

4,4'-Difluoro-8-methoxycarbonyl-1,3,5,7-tetramethyl-2,6-diphenyl-4-bora-3a,4a-diazas-indacene (18). $\mathrm{Pd}\left(\mathrm{PPh}_{3}\right)_{4}\left(0.012 \mathrm{~g}, 0.01 \mathrm{mmol}, 0.05\right.$ equiv.) and $1 \mathrm{M} \mathrm{Cs}_{2} \mathrm{CO}_{3}$ (aq., $4 \mathrm{~mL}$ ) were added to a degassed solution of BODIPY $17(0.120 \mathrm{~g}, 0.21 \mathrm{mmol}, 1$ equiv.) in THF $(15 \mathrm{~mL})$ under nitrogen atmosphere. Phenylboronic acid $(0.100 \mathrm{~g}, 0.84 \mathrm{mmol}, 4$ equiv.) was added portion-wise, and the reaction mixture was stirred under reflux for $6 \mathrm{~h}$ under nitrogen atmosphere. TLC was used to monitor the reaction. When the reaction was complete, water was added, and the mixture was extracted with dichloromethane $(3 \times 10 \mathrm{~mL})$. The collected organic layers were dried over anhydrous magnesium sulfate, filtered, and concentrated to dryness under reduced pressure. The product was purified by flash chromatography on silica gel (cyclohexane/dichloromethane, 6:4) and recrystallization from hexane containing a small amount of dichloromethane. Yield $0.073 \mathrm{~g}(76 \%)$. Red solid. ${ }^{1} \mathrm{H}$ NMR $\left(300 \mathrm{MHz}, \mathrm{CDCl}_{3}\right): \delta(\mathrm{ppm}) 7.48-7.43(\mathrm{~m}, 4 \mathrm{H}), 7.40-7.34(\mathrm{~m}, 2 \mathrm{H}), 7.25-7.22(\mathrm{~m}$, $4 \mathrm{H}), 4.00(\mathrm{~s}, 3 \mathrm{H}), 2.53(\mathrm{~s}, 6 \mathrm{H}), 2.08(\mathrm{~s}, 6 \mathrm{H})$ (Figure S8). ${ }^{13} \mathrm{C} \mathrm{NMR}\left(75 \mathrm{MHz}, \mathrm{CDCl}_{3}\right): \delta$ (ppm) 166.1, 156.5, 136.9, 134.0, 133.04, 133.06, 129.0, 128.6, 128.5, 127.4, 53.2, 13.6, $10.1 \mathrm{ppm}$ (Figure S26). HRMS-APCl${ }^{-} \mathrm{m} / \mathrm{z}$ : [M-H] ${ }^{-}$calculated for $\mathrm{C}_{27} \mathrm{H}_{24} \mathrm{BF}_{2} \mathrm{~N}_{2} \mathrm{O}_{2} 457.1909$, found 457.1913 (Figure S44).

General procedure for Sonogashira coupling: BODIPY 17 (1 equiv.) was dissolved in degassed THF $/ \mathrm{Et}_{3} \mathrm{~N}$ (2:1). The flask was evacuated under nitrogen and $\mathrm{Pd}\left(\mathrm{PPh}_{3}\right)_{2} \mathrm{Cl}_{2}$ was then added ( 0.1 equiv.). After 5 min of a constant flow of nitrogen, $\mathrm{CuI}$ ( 0.1 equiv.) was added and, 5 min later, an ethynyl derivative (5 equiv.) was added. The reaction mixture was stirred at $40{ }^{\circ} \mathrm{C}$ for $1 \mathrm{~h}$ under nitrogen. TLC was used to monitor the reaction. When the reaction was finished, water was added, and the mixture was extracted with dichloromethane $(3 \times 10 \mathrm{~mL})$. The collected organic layers were dried over anhydrous magnesium sulfate, filtered, and concentrated to dryness under reduced pressure. The product was purified by flash chromatography on silica gel and recrystallization.

4,4'-Difluoro-8-methoxycarbonyl-1,3,5,7-tetramethyl-2,6-diphenylethynyl-4-bora-3a,4adiaza-s-indacene (19). The title compound was prepared according to the general procedure for Sonogashira coupling from $17(0.200 \mathrm{~g}, 0.36 \mathrm{mmol}), \mathrm{Pd}\left(\mathrm{PPh}_{3}\right)_{2} \mathrm{Cl}_{2}(0.025 \mathrm{~g}$, $0.036 \mathrm{mmol})$, CuI $(0.007 \mathrm{~g}, 0.036 \mathrm{mmol})$, and phenylacetylene $(0.2 \mathrm{ml}, 1.79 \mathrm{mmol})$ in degassed THF/ $\mathrm{Et}_{3} \mathrm{~N}(2: 1,30 \mathrm{~mL})$; the reaction time was $1 \mathrm{~h}$. It was purified by flash chromatography (hexane/dichloromethane, 7:3) and recrystallization from hexane containing a small amount of dichloromethane. Yield $0.150 \mathrm{~g}(83 \%)$. Blue solid. ${ }^{1} \mathrm{H}$ NMR (300 MHz, $\left.\mathrm{CDCl}_{3}\right): \delta(\mathrm{ppm}) 7.54-7.51(\mathrm{~m}, 4 \mathrm{H}), 7.37-7.35(\mathrm{~m}, 6 \mathrm{H}), 4.04(\mathrm{~s}, 3 \mathrm{H}), 2.71(\mathrm{~s}, 6 \mathrm{H}), 2.27(\mathrm{~s}$, $6 \mathrm{H})$ (Figure S9). ${ }^{13} \mathrm{C}$ NMR $\left(75 \mathrm{MHz}, \mathrm{CDCl}_{3}\right): \delta$ (ppm) 165.1, 160.5, 145.4, 141.5, 131.4, 128.6, 128.41, 128.39, 123.2, 116.6, 97.0, 81.0, 53.4, 13.9, 11.6 (Figure S27). HRMS-APCl ${ }^{+} m / z$ : $[\mathrm{M}+\mathrm{H}]^{+}$calculated for $\mathrm{C}_{31} \mathrm{H}_{26} \mathrm{BF}_{2} \mathrm{~N}_{2} \mathrm{O}_{2}$ 507.2055, found 507.2060 (Figure S45).

4,4'-Difluoro-8-methoxycarbonyl-2,6-di(4-methoxyphenyl)ethynyl-1,3,5,7-tetramethyl4-bora-3a,4a-diaza-s-indacene (20). The title compound was prepared according to the general procedure for Sonogashira coupling from 17 (0.050 g, $0.09 \mathrm{mmol}), \mathrm{Pd}\left(\mathrm{PPh}_{3}\right)_{2} \mathrm{Cl}_{2}$ 
(0.006 g, $0.009 \mathrm{mmol}), \mathrm{CuI}(0.002 \mathrm{~g}, 0.009 \mathrm{mmol})$, and 4-ethynylanisole $(0.06 \mathrm{ml}, 0.45 \mathrm{mmol})$ in degassed THF $/ \mathrm{Et}_{3} \mathrm{~N}(2: 1,8 \mathrm{~mL})$; the reaction time was $1 \mathrm{~h}$. It was purified by flash chromatography (hexane/dichloromethane, 6:4) and recrystallization from hexane containing a small amount of dichloromethane. Yield $0.040 \mathrm{~g}(80 \%)$. Blue solid. ${ }^{1} \mathrm{H}$ NMR $(300 \mathrm{MHz}$, $\left.\mathrm{CDCl}_{3}\right): \delta(\mathrm{ppm}) 7.45(\mathrm{~d}, J=8.7 \mathrm{~Hz}, 4 \mathrm{H}), 6.89(\mathrm{~d}, J=8.7 \mathrm{~Hz}, 4 \mathrm{H}), 4.02(\mathrm{~s}, 3 \mathrm{H}), 3.85(\mathrm{~s}, 6 \mathrm{H})$, $2.69(\mathrm{~s}, 6 \mathrm{H}), 2.25$ (s, 6H) ppm (Figure S10). ${ }^{13} \mathrm{C} \mathrm{NMR} \mathrm{(75} \mathrm{MHz,} \mathrm{CDCl} 3$ ): $\delta$ (ppm) 166.3, $160.3,159.8,141.0,132.9,128.9,128.5,116.8,115.3,114.1,97.0,79.6,55.3,53.2,13.9,11.6$ (Figure S28). HRMS-APCl${ }^{-} m / z$ : $[\mathrm{M}-\mathrm{H}]^{-}$calculated for $\mathrm{C}_{33} \mathrm{H}_{28} \mathrm{BF}_{2} \mathrm{~N}_{2} \mathrm{O}_{2} 565.2121$, found 565.2124 (Figure S46).

4,4'-Difluoro-8-methoxycarbonyl-2,6-di[4-[2-[2-(2-methoxyethoxy)ethoxy]ethoxy]phenyl) ethynyl-1,3,5,7-tetramethyl-4-bora-3a,4a-diaza-s-indacene (21). The title compound was prepared according to the general procedure for Sonogashira coupling from $17(0.200 \mathrm{~g}$, $0.36 \mathrm{mmol}), \mathrm{Pd}\left(\mathrm{PPh}_{3}\right)_{2} \mathrm{Cl}_{2}(0.025 \mathrm{~g}, 0.036 \mathrm{mmol}), \mathrm{CuI}(0.007 \mathrm{~g}, 0.036 \mathrm{mmol})$, and 1-ethynyl4-[2-[2-(2-methoxyethoxy)ethoxy]ethoxybenzene [58] $(0.474 \mathrm{~g}, 1.792 \mathrm{mmol})$ in degassed $\mathrm{THF} / \mathrm{Et}_{3} \mathrm{~N}(2: 1,30 \mathrm{~mL})$; the reaction time was $1.5 \mathrm{~h}$. It was purified by flash chromatography (dichloromethane/ethyl acetate, $3: 7$ ) and recrystallization from hexane containing a small amount of dichloromethane. Yield $0.217 \mathrm{~g}(73 \%)$. Green solid. ${ }^{1} \mathrm{H}$ NMR $(300 \mathrm{MHz}$, $\left.\mathrm{CD}_{2} \mathrm{Cl}_{2}\right): \delta(\mathrm{ppm}) 7.45(\mathrm{~d}, J=8.8 \mathrm{~Hz}, 4 \mathrm{H}), 6.91(\mathrm{~d}, J=8.8 \mathrm{~Hz}, 4 \mathrm{H}), 4.14(\mathrm{t}, J=5.1 \mathrm{~Hz}, 4 \mathrm{H})$, $4.02(\mathrm{~s}, 3 \mathrm{H}), 3.82(\mathrm{t}, J=5.1 \mathrm{~Hz}, 4 \mathrm{H}), 3.70-3.57(\mathrm{~m}, 12 \mathrm{H}), 3.53-3.49(\mathrm{~m}, 4 \mathrm{H}), 3.34(\mathrm{~s}, 6 \mathrm{H}), 2.66$ (s, 6H), 2.25 (s, 6H) (Figure S11). ${ }^{13} \mathrm{C}$ NMR $\left(75 \mathrm{MHz}, \mathrm{CD}_{2} \mathrm{Cl}_{2}\right.$ ): $\delta$ (ppm) 165.5, 160.6, 159.6, 141.6, 134.4, 133.3, 129.6, 129.0, 117.2, 115.8, 115.1, 97.4, 80.0, 72.4, 71.3, 71.0, 70.9, 70.0, 68.1, 59.0, 14.1, 12.0 (Figure S29). HRMS-APCl ${ }^{+} \mathrm{m} / \mathrm{z}$ : $[\mathrm{M}+\mathrm{H}]^{+}$calculated for $\mathrm{C}_{45} \mathrm{H}_{54} \mathrm{BF}_{2} \mathrm{~N}_{2} \mathrm{O}_{10}$ 831.3842, found 831.3846 (Figure S47).

Synthesis of meso-carboxy BODIPYs: general procedure A. A methyl ester of mesocarboxy BODIPYs (1 equiv.) was dissolved in dry ethyl acetate and LiI (10 equiv.) was added. The reaction mixture was heated to reflux for $16 \mathrm{~h}$ under a nitrogen atmosphere. TLC was used to monitor the reaction. When the reaction was finished, the mixture was cooled to room temperature, and a small amount of $\mathrm{HCl}(0.2 \mathrm{~mL})$ was added to quench the reaction. Water was added, and the mixture was extracted with ethyl acetate $(3 \times 10 \mathrm{~mL})$. The combined organic layers were washed with water $(20 \mathrm{~mL})$, dried over anhydrous sodium sulfate, filtered, and concentrated to dryness under reduced pressure. The compounds were purified by flash chromatography on silica gel.

Synthesis of meso-carboxy BODIPYs: general procedure B. A methyl ester of mesocarboxy BODIPYs (1 equiv.) was dissolved in a mixed solution of dry dichloromethane and dry methanol (2:1), and $\mathrm{Pd} / \mathrm{C}(5 \%)$ was added to the solution. A balloon with $\mathrm{H}_{2}$ was connected to the flask, and air was replaced by $\mathrm{H}_{2}$ atmosphere. The reaction mixture was stirred for $15 \mathrm{~min}$ at room temperature. TLC was used to monitor the reaction. When the reaction was finished, the mixture was filtered, and concentrated to dryness under reduced pressure. The compounds were purified by flash chromatography on silica gel.

8-Carboxy-4,4'-difluoro-1,3,5,7-tetramethyl-4-bora-3a,4a-diaza-s-indacene (2). The title compound was prepared according to general procedure A from $11(0.040 \mathrm{~g}$, $0.13 \mathrm{mmol})$ and LiI $(0.175 \mathrm{~g}, 1.3 \mathrm{mmol})$ in dry ethyl acetate $(20 \mathrm{~mL})$; the reaction time was $14 \mathrm{~h}$. It was purified by flash chromatography (ethyl acetate/methanol, 9:1). Yield $0.026 \mathrm{~g}(69 \%)$. Orange solid. ${ }^{1} \mathrm{H}$ NMR (300 MHz, $\left.\mathrm{CD}_{3} \mathrm{OD}\right): \delta(\mathrm{ppm}) 6.07$ (s, 2H), 2.44 (s, 6H), $2.36(\mathrm{~s}, 6 \mathrm{H})$ (Figure S12). ${ }^{13} \mathrm{C}$ NMR $\left(75 \mathrm{MHz}, \mathrm{CD}_{3} \mathrm{OD}\right): \delta(\mathrm{ppm}) 155.4,142.8$, 140.7, 129.40, 129.38, 120.7, 14.5, 13.0 (Figure S30). HRMS-ESI ${ }^{-} \mathrm{m} / z$ : $[\mathrm{M}-\mathrm{H}]^{-}$calculated for $\mathrm{C}_{14} \mathrm{H}_{14} \mathrm{BF}_{2} \mathrm{~N}_{2} \mathrm{O}_{2} 291.1124$, found 291.1122 (Figure S48). The spectroscopic data are in good agreement with those from the literature [37].

8-Carboxy-4,4'-difluoro-2,6-diiodo-1,3,5,7-tetramethyl-4-bora-3a,4a-diaza-s-indacene (4). The title compound was prepared according to general procedure A from 17 ( $0.100 \mathrm{~g}$, $0.179 \mathrm{mmol})$ and Lil $(0.240 \mathrm{~g}, 1.79 \mathrm{mmol})$ in dry ethyl acetate $(50 \mathrm{~mL})$; the reaction time was $15 \mathrm{~h}$. It was purified by flash chromatography (ethyl acetate/methanol, 9:1). Yield $0.071 \mathrm{~g}(73 \%)$. Red solid. ${ }^{1} \mathrm{H}$ NMR (300 MHz, $\left.\mathrm{CD}_{3} \mathrm{OD}\right): \delta(\mathrm{ppm}) 2.53(\mathrm{~s}, 6 \mathrm{H}), 2.38(\mathrm{~s}, 6 \mathrm{H})$ (Figure S14). ${ }^{13} \mathrm{C}$ NMR (125 MHz, $\left.\mathrm{CD}_{3} \mathrm{OD}\right): \delta$ (ppm) 170.5, 156.4, 145.0, 141.0, 129.0, 
84.0, 16.0, 15.6 (Figure S32). HRMS-APCl ${ }^{-} m / z:[\mathrm{M}-\mathrm{H}]^{-}$calculated for $\mathrm{C}_{14} \mathrm{H}_{12} \mathrm{BF}_{2} \mathrm{I}_{2} \mathrm{~N}_{2} \mathrm{O}_{2}$ 542.9057 , found 542.9054 (Figure S50).

2,8-Dicarboxy-4,4'-difluoro-1,3,5,7-tetramethyl-4-bora-3a,4a-diaza-s-indacene (5). The title compound was prepared according to general procedure B from $\mathbf{1 4}(0.08 \mathrm{~g}, 0.18 \mathrm{mmol})$ and $\mathrm{Pd} / \mathrm{C}(0.01 \mathrm{~g}, 0.009 \mathrm{mmol})$ in dry dichloromethane $(3 \mathrm{~mL})$ and dry methanol $(6 \mathrm{~mL})$; the reaction time was $15 \mathrm{~min}$. It was purified by flash chromatography (ethyl acetate/methanol, 2:1). Yield $0.045 \mathrm{~g}(71 \%)$. Dark red solid. ${ }^{1} \mathrm{H}$ NMR (300 MHz, $\left.\mathrm{CD}_{3} \mathrm{OD}\right): \delta(\mathrm{ppm}) 6.14(\mathrm{~s}, 1 \mathrm{H})$, $2.51(\mathrm{~s}, 6 \mathrm{H}), 2.42(\mathrm{~s}, 6 \mathrm{H})$ (Figure S15). ${ }^{13} \mathrm{C}$ NMR $\left(75 \mathrm{MHz}, \mathrm{CD}_{3} \mathrm{OD}\right): \delta(\mathrm{ppm}) 171.4,155.5$, 142.8, 140.6, 129.4, 120.8, 14.5, 13.0 (Figure S33). HRMS-ESI ${ }^{-} \mathrm{m} / \mathrm{z}$ : $[\mathrm{M}-\mathrm{H}]^{-}$calculated for $\mathrm{C}_{15} \mathrm{H}_{14} \mathrm{BF}_{2} \mathrm{~N}_{2} \mathrm{O}_{4}$ 335.1023, found 335.1021 (Figure S51).

8-Carboxy-2-cyano-4,4' -difluoro-1,3,5,7-tetramethyl-4-bora-3a,4a-diaza-s-indacene (6). The title compound was prepared according to general procedure B from $16(0.04 \mathrm{~g}$, $0.10 \mathrm{mmol})$ and $\mathrm{Pd} / \mathrm{C}(0.005 \mathrm{~g}, 0.005 \mathrm{mmol})$ in dry dichloromethane $(3 \mathrm{~mL})$ and dry methanol (6 mL); the reaction time was $15 \mathrm{~min}$. Purified by flash chromatography (ethyl acetate/methanol, 2:1). Yield $0.021 \mathrm{~g}(65 \%)$. Dark red solid. ${ }^{1} \mathrm{H}$ NMR $\left(300 \mathrm{MHz}, \mathrm{CD}_{3} \mathrm{OD}\right) \delta$ (ppm) $6.41(\mathrm{~s}, 1 \mathrm{H}), 2.63(\mathrm{~s}, 3 \mathrm{H}), 2.61(\mathrm{~s}, 3 \mathrm{H}), 2.63(\mathrm{~s}, 3 \mathrm{H}), 2.52(\mathrm{~s}, 3 \mathrm{H}), 2.49(\mathrm{~s}, 3 \mathrm{H})$, (Figure S16). ${ }^{13} \mathrm{C}$ NMR (75 MHz, CD 3 OD): $\delta$ (ppm) 169.9, 163.8, 153.8, 148.5, 141.4, 140.8, 132.4, 127.2, $124.2,116.0,101.9,15.0,13.3,13.2,11.7$ (Figure S34). HRMS-ESI ${ }^{-} \mathrm{m} / z$ : $[\mathrm{M}-\mathrm{H}]^{-}$calculated for $\mathrm{C}_{15} \mathrm{H}_{13} \mathrm{BF}_{2} \mathrm{~N}_{3} \mathrm{O}_{2}$ 316.1077, found 316.1078 (Figure S52).

8-Carboxy-4,4'-difluoro-1,3,5,7-tetramethyl-2,6-diphenyl-4-bora-3a,4a-diaza-s-indacene (7). The title compound was prepared according to general procedure A from 18 ( $0.040 \mathrm{~g}$, $0.09 \mathrm{mmol})$ and LiI $(0.117 \mathrm{~g}, 0.9 \mathrm{mmol})$ in dry ethyl acetate $(20 \mathrm{~mL})$; the reaction time was $15 \mathrm{~h}$. Purified by flash chromatography (ethyl acetate/methanol, 9:1). Yield $0.032 \mathrm{~g}(81 \%)$. Red solid. ${ }^{1} \mathrm{H}$ NMR $\left(300 \mathrm{MHz}, \mathrm{CD}_{3} \mathrm{OD}\right): \delta(\mathrm{ppm}) 7.47-7.42(\mathrm{~m}, 4 \mathrm{H}), 7.37-7.32(\mathrm{~m}, 2 \mathrm{H})$, 7.24-7.22 (m, 2H), $2.42(\mathrm{~s}, 6 \mathrm{H}), 2.31(\mathrm{~s}, 6 \mathrm{H})$ (Figure S17). ${ }^{13} \mathrm{C} \mathrm{NMR}\left(75 \mathrm{MHz}, \mathrm{CD}_{3} \mathrm{OD}\right): \delta$ (ppm) 172.2, 154.2, 140.1, 138.6, 135.1, 134.0, 131.2, 129.40, 129.1, 128.2, 13.4, 11.5 (Figure S35). HRMS-ESI ${ }^{-} \mathrm{m} / \mathrm{z}$ : $[\mathrm{M}-\mathrm{H}]^{-}$calculated for $\mathrm{C}_{26} \mathrm{H}_{22} \mathrm{BF}_{2} \mathrm{~N}_{2} \mathrm{O}_{2} 443.1753$, found 443.1745 (Figure S53).

8-Carboxy-4,4'-difluoro-1,3,5,7-tetramethyl-2,6-phenylethynyl-4-bora-3a,4a-diaza-sindacene (8). The title compound was prepared according to general procedure A from $19(0.090 \mathrm{~g}, 0.178 \mathrm{mmol})$ and LiI $(0.238 \mathrm{~g}, 1.78 \mathrm{mmol})$ in dry ethyl acetate $(80 \mathrm{~mL})$; the reaction time was $16 \mathrm{~h}$. Purified by flash chromatography (ethyl acetate/methanol, 9:1). Yield $0.081 \mathrm{~g}(92 \%)$. Red solid. ${ }^{1} \mathrm{H}$ NMR $\left(300 \mathrm{MHz}, \mathrm{CD}_{3} \mathrm{OD}\right): \delta(\mathrm{ppm}) 7.52-7.50(\mathrm{~m}, 4 \mathrm{H})$, 7.40-7.34 (m, 6H), $2.62(\mathrm{~s}, 6 \mathrm{H}), 2.51(\mathrm{~s}, 6 \mathrm{H})$ (Figure S18). ${ }^{13} \mathrm{C} \mathrm{NMR}\left(75 \mathrm{MHz}, \mathrm{CD}_{3} \mathrm{OD}\right): \delta$ (ppm) 170.4, 158.0, 143.6, 141.7, 132.3, 129.5, 129.2, 129.0, 124.8, 115.9, 97.2, 82.3, 13.6, 12.1 (Figure S36). HRMS-ESI ${ }^{-} \mathrm{m} / \mathrm{z}$ : $[\mathrm{M}-\mathrm{H}]^{-}$calculated for $\mathrm{C}_{30} \mathrm{H}_{22} \mathrm{BF}_{2} \mathrm{~N}_{2} \mathrm{O}_{2}$ 491.1753, found 491.1756 (Figure S54).

8-Carboxy-4,4'-difluoro-2,6-di(4-methoxyphenyl)ethynyl-1,3,5,7-tetramethyl-4-bora3a,4a-diaza-s-indacene (9). The title compound was prepared according to general procedure A from $20(0.020 \mathrm{~g}, 0.035 \mathrm{mmol})$ and LiI $(0.047 \mathrm{~g}, 0.35 \mathrm{mmol})$ in dry ethyl acetate $(20 \mathrm{~mL})$; the reaction time was $16 \mathrm{~h}$. Purified by flash chromatography (ethyl acetate/methanol, 9:1). Yield $0.015 \mathrm{~g}(79 \%)$. Purple solid. ${ }^{1} \mathrm{H}$ NMR $\left(\mathrm{CD}_{3} \mathrm{OD}, 300 \mathrm{MHz}\right): \delta(\mathrm{ppm}) 7.43(\mathrm{~d}$, $J=8.8 \mathrm{~Hz}, 4 \mathrm{H}), 6.92(\mathrm{~d}, J=8.8 \mathrm{~Hz}, 4 \mathrm{H}), 3.82(\mathrm{~s}, 6 \mathrm{H}), 2.60(\mathrm{~s}, 6 \mathrm{H}), 2.49(\mathrm{~s}, 6 \mathrm{H})$ (Figure S19). ${ }^{13} \mathrm{C}$ NMR $\left(125 \mathrm{MHz}, \mathrm{CD}_{3} \mathrm{OD}\right): \delta$ (ppm) 170.5, 161.4, 158.0, 143.1, 133.8, 129.0, 116.8, 116.3, 115.2, 97.2, 80.8, 55.8, 13.6, 12.1 (Figure S37). HRMS-ESI ${ }^{-} \mathrm{m} / \mathrm{z}$ : [M-H] ${ }^{-}$calculated for $\mathrm{C}_{32} \mathrm{H}_{26} \mathrm{BF}_{2} \mathrm{~N}_{2} \mathrm{O}_{4} 551.1965$, found 551.1962 (Figure S55).

8-Carboxy-4,4'-difluoro-2,6-di[4-[2-[2-(2-methoxyethoxy)ethoxy]ethoxy]phenyl)ethynyl1,3,5,7-tetramethyl-4-bora-3a,4a-diaza-s-indacene (10). The title compound was prepared according to the general procedure A from $21(0.070 \mathrm{~g}, 0.084 \mathrm{mmol})$ and LiI $(0.112 \mathrm{~g}$, $0.84 \mathrm{mmol})$ in dry ethyl acetate $(60 \mathrm{~mL})$; the reaction time was $16 \mathrm{~h}$. Purified by flash chromatography (ethyl acetate/methanol, 9:1). Yield $0.056 \mathrm{~g}(82 \%)$. Blue solid. ${ }^{1} \mathrm{H}$ NMR (300 MHz, CD 3 OD): $\delta(\mathrm{ppm}) 7.43(\mathrm{~d}, J=8.8 \mathrm{~Hz}, 4 \mathrm{H}), 6.95(\mathrm{~d}, J=8.8 \mathrm{~Hz}, 4 \mathrm{H}), 4.16(\mathrm{t}$, $J=4.9 \mathrm{~Hz}, 4 \mathrm{H}), 3.85(\mathrm{t}, J=4.9 \mathrm{~Hz}, 4 \mathrm{H}), 3.72-3.62(\mathrm{~m}, 12 \mathrm{H}), 3.55-3.52(\mathrm{~m}, 4 \mathrm{H}), 3.35(\mathrm{~s}, 6 \mathrm{H})$, $2.60(\mathrm{~s}, 6 \mathrm{H}), 2.49(\mathrm{~s}, 6 \mathrm{H})$ (Figure S20). ${ }^{13} \mathrm{C}$ NMR (75 MHz, CD $\left.{ }_{3} \mathrm{OD}\right): \delta(\mathrm{ppm}) 170.3,160.3$, 
157.8, 143.1, 141.7, 133.8, 129.1, 117.1, 116.2, 115.9, 97.2, 80.9, 72.8, 71.6, 71.4, 71.2, 70.7, 68.7, 59.1, 13.7, 12.1 (Figure S38). HRMS-ESI ${ }^{-} \mathrm{m} / \mathrm{z}$ : $[\mathrm{M}-\mathrm{H}]^{-}$calculated for $\mathrm{C}_{44} \mathrm{H}_{50} \mathrm{BF}_{2} \mathrm{~N}_{2} \mathrm{O}_{10}$ 815.3540, found 815.3540 (Figure S56).

2,6-Dibromo-8-carboxy-4,4'-difluoro-1,3,5,7-tetramethyl-4-bora-3a,4a-diaza-s-indacene (3). BODIPY $1(0.04 \mathrm{~g}, 0.14 \mathrm{mmol}, 1$ equiv.) was solved in a mixed solution of dichloromethane/DMF (1:1), and NBS (0.05 g, $0.29 \mathrm{mmol}, 2.1$ equiv.) was added. The solution was stirred $4 \mathrm{~h}$ at room temperature. The reaction was quenched with water, and the organic matter was extracted with dichloromethane. The organic layers were washed with water, dried over anhydrous magnesium sulfate, filtered, and the solvent was evaporated under reduced pressure. The crude mixture was purified by flash chromatography (ethyl acetate/methanol 9:1 to 7:1). Yield $0.03 \mathrm{~g}(49 \%)$. Orange powder. ${ }^{1} \mathrm{H}$ NMR (300 $\left.\mathrm{MHz}, \mathrm{CD}_{3} \mathrm{OD}\right): \delta$ (ppm) $2.50(\mathrm{~s}, 6 \mathrm{H}), 2,36$ (s, 6H) (Figure S13). ${ }^{13} \mathrm{C}$ NMR $\left(125 \mathrm{MHz}, \mathrm{CD}_{3} \mathrm{OD}\right): \delta$ (ppm) 170.2, 153.4, 141.5, 140.3, 128.1, 110.8, 13.6, 12.4 (Figure S31). HRMS-ESI ${ }^{-} \mathrm{m} / \mathrm{z}$ : $[\mathrm{M}-\mathrm{H}]^{-}$calculated for $\mathrm{C}_{14} \mathrm{H}_{14} \mathrm{BBr}_{2} \mathrm{~F}_{2} \mathrm{~N}_{2} \mathrm{O}_{2} 448.9315$, found 448.9311 (Figure S49).

\section{Conclusions}

We report the synthesis and photophysical and photochemical properties of a series of 2,6-substituted meso-carboxy BODIPY derivatives designed as photoactivatable CO-releasing molecules (photoCORMs). The results provide valuable insights into the structural and electronic factors that affect their photoreactivity. We show that the methyl substituents at positions 1 and 7, originally introduced to improve the chemical stability of BODIPY derivatives, play an unfavorable role in the release of $\mathrm{CO}$. Neither the enhancement of intersystem crossing by heavy-atom substituents nor the decrease in the electron density thanks to electron-withdrawing substituents improved the $\mathrm{CO}$ yields. However, $\mathrm{CO}$ was efficiently released from $\pi$-extended 2,6-arylethynyl BODIPY derivatives with absorption spectra shifted toward a more biologically desirable wavelength range. Subsequently, in vitro cytotoxicity experiments with the most potent meso-carboxy BODIPY photoCORMs and their photoproducts did not reveal any major toxic effects, which justifies them for further biological studies.

Supplementary Materials: The following are available online at https://www.mdpi.com/2624 -8549/3/1/18/s1, Figures S1-S38: NMR spectra; Figures S39-S56: HRMS analyses; Figures S57S73: Absorption and fluorescence spectra; Figures S74-S76: Stabilities in the dark; Figures S77S94: Photochemical experiments; Figures S95-S99: Singlet oxygen experiments; Figures S100-S115: Transient absorption data; Table S1: Transient lifetimes; Figures S116-S117: Cell viabilities; Page S82: Determination of intersystem crossing quantum yields; Pages S84-S85: Analyses of photoproducts.

Author Contributions: E.M.S.-C. performed the synthesis (compounds 2, 4, 7, 8, 9, and 10) and photochemical experiments. M.R. performed both the steady-state and transient-absorption spectroscopy. A.J. performed the synthesis (compounds 3, 5, and 6) and photochemical experiments. L.M. performed the biological experiments. E.M.S.-C., M.R., L.M., L.V., and P.K. co-wrote the manuscript. All authors have read and agreed to the published version of the manuscript.

Funding: Support for this work was provided by the Czech Science Foundation (GA18-12477S), and the Czech Ministry of Health (RVO-VFN64165/2020, L.V.). We thank the CETOCOEN EXCELLENCE Teaming 2 project (supported by the Czech Ministry of Education, Youth, and Sports: CZ.02.1.01/0.0/0.0/17_043/0009632 and EU H2020: 857560) and the RECETOX research infrastructure (LM2018121).

Institutional Review Board Statement: Not applicable.

Informed Consent Statement: Not applicable.

Data Availability Statement: The data presented in this study are available in the Supplementary Materials.

Acknowledgments: The authors thank Lukas Maier (Masaryk University) for the NMR analyses, Miroslava Bittova (Masaryk University) for the HRMS analyses, and Orazio Angelo Arcidiacono (Czech Academy of Sciences) for the preparation of a graphical abstract. 
Conflicts of Interest: The authors declare no conflict of interest.

\section{References}

1. Wood, T.E.; Thompson, A. Advances in the chemistry of dipyrrins and their complexes. Chem. Rev. 2007, 107, 1831-1861. [CrossRef]

2. Ulrich, G.; Ziessel, R.; Harriman, A. The chemistry of fluorescent BODIPY dyes: Versatility unsurpassed. Angew. Chem. Int. Ed. 2008, 47, 1184-1201. [CrossRef]

3. Benniston, A.C.; Copley, G. Lighting the way ahead with boron dipyrromethene (BODIPY) dyes. Phys. Chem. Chem. Phys. 2009, 11, 4124-4131. [CrossRef] [PubMed]

4. Deniz, E.; Isbasar, G.C.; Bozdemir, O.A.; Yildirim, L.T.; Siemiarczuk, A.; Akkaya, E.U. Bidirectional switching of near IR emitting boradiazaindacene fluorophores. Org. Lett. 2008, 10, 3401-3403. [CrossRef]

5. Niu, L.-Y.; Guan, Y.-S.; Chen, Y.-Z.; Wu, L.-Z.; Tung, C.-H.; Yang, Q.-Z. BODIPY-based ratiometric fluorescent sensor for highly selective detection of glutathione over cysteine and homocysteine. J. Am. Chem. Soc. 2012, 134, 18928-18931. [CrossRef] [PubMed]

6. Ikawa, Y.; Moriyama, S.; Furuta, H. Facile syntheses of BODIPY derivatives for fluorescent labeling of the $3^{\prime}$ and $5^{\prime}$ Ends of RNAs. Anal. Biochem. 2008, 378, 166-170. [CrossRef] [PubMed]

7. Zheng, Q.; Xu, G.; Prasad, P.N. Conformationally restricted dipyrromethene boron difluoride (BODIPY) dyes: Highly fluorescent, multicolored probes for cellular imaging. Chem. Eur. J. 2008, 14, 5812-5819. [CrossRef] [PubMed]

8. Kamkaew, A.; Lim, S.H.; Lee, H.B.; Kiew, L.V.; Chung, L.Y.; Burgess, K. BODIPY dyes in photodynamic therapy. Chem. Soc. Rev. 2013, 42, 77-88. [CrossRef]

9. Bessette, A.; Hanan, G.S. Design, synthesis and photophysical studies of dipyrromethene-based materials: Insights into their applications in organic photovoltaic devices. Chem. Soc. Rev. 2014, 43, 3342-3405. [CrossRef]

10. Boens, N.; Leen, V.; Dehaen, W. Fluorescent indicators based on BODIPY. Chem. Soc. Rev. 2012, 41, 1130-1172. [CrossRef]

11. Loudet, A.; Burgess, K. BODIPY dyes and their derivatives: Syntheses and spectroscopic properties. Chem. Rev. 2007, 107, 4891-4932. [CrossRef]

12. Boens, N.; Verbelen, B.; Dehaen, W. Postfunctionalization of the BODIPY core: Synthesis and spectroscopy. Eur. J. Org. Chem. 2015, 2015, 6577-6595. [CrossRef]

13. DeRosa, M. Photosensitized singlet oxygen and its applications. Coord. Chem. Rev. 2002, 233, 351-371. [CrossRef]

14. Al Anshori, J.; Slanina, T.; Palao, E.; Klán, P. The internal heavy-atom effect on 3-Phenylselanyl and 3-Phenyltellanyl bodipy derivatives studied by transient absorption spectroscopy. Photochem. Photobiol. Sci. 2016, 15, 250-259. [CrossRef] [PubMed]

15. Yogo, T.; Urano, Y.; Ishitsuka, Y.; Maniwa, F.; Nagano, T. Highly efficient and photostable photosensitizer based on BODIPY chromophore. J. Am. Chem. Soc. 2005, 127, 12162-12163. [CrossRef] [PubMed]

16. Michl, J.; Bonačić-Koutecký, V. Electronic Aspects of Organic Photochemistry; Wiley: Chichester, UK, 1990.

17. Adarsh, N.; Avirah, R.R.; Ramaiah, D. Tuning photosensitized singlet oxygen generation efficiency of Novel Aza-BODIPY dyes. Org. Lett. 2010, 12, 5720-5723. [CrossRef] [PubMed]

18. Awuah, S.G.; Polreis, J.; Biradar, V.; You, Y. Singlet oxygen generation by Novel NIR BODIPY dyes. Org. Lett. 2011, 13, 3884-3887. [CrossRef]

19. García-Gallego, S.; Bernardes, G.J.L. Carbon-monoxide-releasing molecules for the delivery of therapeutic CO in vivo. Angezw. Chem. Int. Ed. 2014, 53, 9712-9721. [CrossRef]

20. Motterlini, R.; Otterbein, L.E. The therapeutic potential of carbon monoxide. Nat. Rev. Drug Discov. 2010, 9, 728-743. [CrossRef]

21. Romão, C.C.; Blättler, W.A.; Seixas, J.D.; Bernardes, G.J.L. Developing drug molecules for therapy with carbon monoxide. Chem. Soc. Rev. 2012, 41, 3571-3583. [CrossRef]

22. Chakraborty, I.; Carrington, S.J.; Mascharak, P.K. Design strategies to improve the sensitivity of photoactive metal Carbonyl complexes (photoCORMs) to visible light and their potential as CO-donors to biological targets. Acc. Chem. Res. 2014, 47, 2603-2611. [CrossRef]

23. Rudolf, P.; Kanal, F.; Knorr, J.; Nagel, C.; Niesel, J.; Brixner, T.; Schatzschneider, U.; Nuernberger, P. Ultrafast photochemistry of a manganese-tricarbonyl CO-releasing molecule (CORM) in aqueous solution. J. Phys. Chem. Lett. 2013, 4, 596-602. [CrossRef]

24. Slanina, T.; Sebej, P. Visible-light-activated photoCORMs: Rational design of CO-releasing organic molecules absorbing in the tissue-transparent window. Photochem. Photobiol. Sci. 2018, 17, 692-710. [CrossRef] [PubMed]

25. Marhenke, J.; Trevino, K.; Works, C. The chemistry, biology and design of photochemical CO releasing Molecules and the efforts to detect CO for biological applications. Coord. Chem. Rev. 2016, 306, 533-543. [CrossRef]

26. Schatzschneider, U. PhotoCORMs: Light-triggered release of carbon monoxide from the coordination sphere of transition metal complexes for biological applications. Inorg. Chim. Acta 2011, 374, 19-23. [CrossRef]

27. Ling, K.; Men, F.; Wang, W.C.; Zhou, Y.Q.; Zhang, H.W.; Ye, D.W. Carbon monoxide and its controlled release: Therapeutic application, detection, and development of carbon monoxide releasing molecules (CORMs). J. Med. Chem. 2018, 61, 2611-2635. [CrossRef]

28. Weinstain, R.; Slanina, T.; Kand, D.; Klán, P. Visible-to-NIR-light activated release: From small molecules to nanomaterials. Chem. Rev. 2020, 120, 13135-13272. [CrossRef] [PubMed]

29. Cheong, W.F.; Prahl, S.A.; Welch, A.J. A review of the optical properties of biological tissues. IEEE J. Quantum Electron. 1990, 26, 2166-2185. [CrossRef] 
30. Tuchin, V.V. Tissue Optics: Light Scattering Methods and Instruments for Medical Diagnostics; SPIE Press: Bellingham, WA, USA, 2015.

31. Antony, L.A.P.; Slanina, T.; Šebej, P.; Šolomek, T.; Klán, P. Fluorescein analogue xanthene-9-carboxylic acid: A transition-metal-free CO releasing molecule activated by green light. Org. Lett. 2013, 15, 4552-4555. [CrossRef] [PubMed]

32. Russo, M.; Štacko, P.; Nachtigallová, D.; Klán, P. Mechanisms of orthogonal photodecarbonylation reactions of 3-hydroxyflavonebased acid-base forms. J. Org. Chem. 2020, 85, 3527-3537. [CrossRef]

33. Štacková, L.; Russo, M.; Muchová, L.; Orel, V.; Vítek, L.; Štacko, P.; Klán, P. Cyanine-flavonol hybrids for near-infrared lightactivated delivery of carbon monoxide. Chem. Eur. J. 2020, 26, 13184-13190. [CrossRef] [PubMed]

34. Lazarus, L.S.; Benninghoff, A.D.; Berreau, L.M. Development of triggerable, trackable, and targetable carbon monoxide releasing molecules. Acc. Chem. Res. 2020, 53, 2273-2285. [CrossRef] [PubMed]

35. Anderson, S.N.; Richards, J.M.; Esquer, H.J.; Benninghoff, A.D.; Arif, A.M.; Berreau, L.M. A structurally-tunable 3-hydroxyflavone motif for visible light-induced carbon monoxide-releasing molecules (CORMs). ChemistryOpen 2015, 4, 590-594. [CrossRef] [PubMed]

36. Palao, E.; Slanina, T.; Muchová, L.; Šolomek, T.; Vítek, L.; Klán, P. Transition-metal-free CO-releasing BODIPY derivatives activatable by visible to NIR light as promising bioactive molecules. J. Am. Chem. Soc. 2015, 138, 126-133. [CrossRef] [PubMed]

37. Ni, Y.; Zeng, L.; Kang, N.-Y.; Huang, K.-W.; Wang, L.; Zeng, Z.; Chang, Y.-T.; Wu, J. meso-Ester and carboxylic acid substituted BODIPYs with far-red and near-infrared emission for bioimaging applications. Chem. Eur. J. 2014, 20, 2301-2310. [CrossRef]

38. Orte, A.; Debroye, E.; Ruedas-Rama, M.J.; Garcia-Fernandez, E.; Robinson, D.; Crovetto, L.; Talavera, E.M.; Alvarez-Pez, J.M.; Leen, V.; Verbelen, B.; et al. Effect of the substitution position $(2,3$ or 8$)$ on the spectroscopic and photophysical properties of BODIPY dyes with a Phenyl, Styryl or Phenylethynyl group. RSC Adv. 2016, 6, 102899-102913. [CrossRef]

39. Lu, H.; Mack, J.; Yang, Y.; Shen, Z. Structural modification strategies for the rational design of red/NIR region BODIPYs. Chem. Soc. Rev. 2014, 43, 4778-4823. [CrossRef]

40. Lu , H.; Wang, Q.; Gai, L.; Li, Z.; Deng, Y.; Xiao, X.; Lai, G.; Shen, Z. Tuning the solid-state luminescence of BODIPY derivatives with Bulky Arylsilyl groups: Synthesis and spectroscopic properties. Chem. Eur. J. 2012, 18, 7852-7861. [CrossRef]

41. Leen, V.; Leemans, T.; Boens, N.; Dehaen, W. 2-and 3-Monohalogenated BODIPY dyes and their functionalized analogues: Synthesis and spectroscopy. Eur. J. Org. Chem. 2011, 2011, 4386-4396. [CrossRef]

42. Jiao, L.; Yu, C.; Wang, J.; Briggs, E.A.; Besley, N.A.; Robinson, D.; Ruedas-Rama, M.J.; Orte, A.; Crovetto, L.; Talavera, E.M.; et al. Unusual spectroscopic and photophysical properties of meso-tert-Butyl BODIPY in comparison to related alkylated BODIPY dyes. RSC Adv. 2015, 5, 89375-89388. [CrossRef]

43. Prlj, A.; Fabrizio, A.; Corminboeuf, C. Rationalizing fluorescence quenching in meso-BODIPY dyes. Phys. Chem. Chem. Phys. 2016, 18, 32668-32672. [CrossRef] [PubMed]

44. Prlj, A.; Vannay, L.; Corminboeuf, C. Fluorescence quenching in BODIPY dyes: The role of intramolecular interactions and charge transfer. Helv. Chim. Acta 2017, 100, e1700093. [CrossRef]

45. Marfin, Y.S.; Shipalova, M.V.; Kurzin, V.O.; Ksenofontova, K.V.; Solomonov, A.V.; Rumyantsev, E.V. Fluorescent properties of BODIPY sensors based on photoinduced electron transfer. J. Fluoresc. 2016, 26, 2105-2112. [CrossRef] [PubMed]

46. Ludvíková, L.; Friš, P.; Heger, D.; Šebej, P.; Wirz, J.; Klán, P. Photochemistry of rose bengal in water and acetonitrile: A comprehensive kinetic analysis. Phys. Chem. Chem. Phys. 2016, 18, 16266-16273. [CrossRef]

47. Palao, E.; Duran-Sampedro, G.; de la Moya, S.; Madrid, M.; García-López, C.; Agarrabeitia, A.R.; Verbelen, B.; Dehaen, W.; Boens, N.; Ortiz, M.J. Exploring the application of the negishi reaction of HaloBODIPYs: Generality, regioselectivity, and synthetic utility in the development of BODIPY laser dyes. J. Org. Chem. 2016, 81, 3700-3710. [CrossRef]

48. Montalti, M.; Murov, S.L. Handbook of Photochemistry, 3rd ed.; CRC; Taylor \& Francis: Boca Raton, FL, USA, 2006 ; p. 650.

49. Slanina, T.; Shrestha, P.; Palao, E.; Kand, D.; Peterson, J.A.; Dutton, A.S.; Rubinstein, N.; Weinstain, R.; Winter, A.H.; Klán, P. In search of the perfect photocage: Structure-reactivity relationships in meso-Methyl BODIPY photoremovable protecting groups. $J$. Am. Chem. Soc. 2017, 139, 15168-15175. [CrossRef] [PubMed]

50. Lachish, U.; Shafferman, A.; Stein, G. Intensity dependence in laser flash photolysis experiments: Hydrated electron formation from ferrocyanide, tyrosine, and tryptophan. J. Chem. Phys. 1976, 64, 4205-4211. [CrossRef]

51. Jacques, P.; Braun, A.M. Laser flash photolysis of phthalocyanines in solution and microemulsion. Helv. Chim. Acta 1981, 64, 1800-1806. [CrossRef]

52. Shen, F.; Wang, T.; Yu, X.; Li, Y. Free radical oxidation reaction for selectively solvatochromic sensors with dynamic sensing ability. Chin. Chem. Lett. 2020, 31, 1919-1922. [CrossRef]

53. Leen, V.; Gonzalvo, V.Z.; Deborggraeve, W.M.; Boens, N.; Dehaen, W. Direct functionalization of BODIPY dyes by oxidative nucleophilic hydrogen substitution at the 3- or 3,5-positions. Chem. Commun. 2010, 46, 4908-4910. [CrossRef]

54. Kim, S.; Bouffard, J.; Kim, Y. Tailoring the solid-state fluorescence emission of BODIPY dyes by meso substitution. Chem. Eur. J. 2015, 21, 17459-17465. [CrossRef] [PubMed]

55. Martínek, M.; Filipová, L.; Galeta, J.; Ludvíková, L.; Klán, P. Photochemical formation of dibenzosilacyclohept-4-yne for Cu-free click chemistry with azides and 1,2,4,5-Tetrazines. Org. Lett. 2016, 18, 4892-4895. [CrossRef] [PubMed]

56. Šolomek, T.; Heger, D.; Ngoy, B.P.; Givens, R.S.; Klán, P. The pivotal role of Oxyallyl diradicals in photo-favorskii rearrangements: Transient spectroscopic and computational studies. J. Am. Chem. Soc. 2013, 135, 15209-15215. [CrossRef] [PubMed] 
57. Vaňková, K.; Marková, I.; Jašprová, J.; Dvořák, A.; Subhanová, I.; Zelenka, J.; Novosádová, I.; Rasl, J.; Vomastek, T.; Sobotka, R.; et al. Chlorophyll-mediated changes in the redox status of pancreatic cancer cells are associated with its anticancer effects. Oxid. Med. Cell. Longev. 2018, 2018, 4069167. [CrossRef]

58. D'Aléo, A.; Picot, A.; Baldeck, P.L.; Andraud, C.; Maury, O. Design of dipicolinic acid ligands for the two-photon sensitized luminescence of europium complexes with optimized cross-sections. Inorg. Chem. 2008, 47, 10269-10279. [CrossRef] [PubMed] 